\title{
Chapter 12. Rivals and Wives: Affinal Politics and the Tongan Ramage
}

\section{Aletta Biersack}

Tongan $h a^{\prime} a$ are agnatically grouped clusters of titles that are ranked according to a rule of historical - and, in the case of the apical ancestor, mythical emergence or precedence (cf. Fox 1994, 1995). Since elder brother outranks younger brother and father outranks son, "elder brother" or "father" titles outrank "younger brother" or "son" titles, the "branches" (va'ava'a) of the Tongan ramage or "origin structure" (Fox 1988) being graded according to relative proximity to an original "root" (tefito). Mythically, if not historically, this root is the Tu'i Tonga or high chief of Tonga (Figure 1) (Sahlins 1958:ch.1). While these botanic idioms suggest a centred, self-totalizing, and self-generating "origin structure" (Fox 1995), they are as important for what they conceal as for what they reveal. Precedence may reflect affinity and the dynamics of the system rather than descent and the statics of the system (cf. ibid.:12-13). ${ }^{1}$

In any effort to explore the mobilities and instabilities of Polynesian systems, Irving Goldman's Ancient Polynesian Society offers some crucial insights. There Goldman places "status rivalry" - a jockeying for position at the top motivated by a systemic "ambiguity of rank" (Goldman 1970:24) — at the heart of these societies. Ambiguity of rank is created by the complexity of the ranking system. “Hereditary rank ... is no single factor, but a compound of multiple genealogical criteria ..." (ibid.:5).

In Tonga (but also elsewhere in Polynesia), senior and junior brothers, senior and junior dynasties, typically contended for top honours. "It was ... a frequent theme that younger brothers and junior lines of descent, although lower in rank, came to be greater in de facto political power and eventually 'upstaged' the senior line" (Bott 1982:62). The competition often (though not always) aligns matrilateral half-brothers, who do not compete for the same titles, against patrilateral half-brothers, who do (Bott 1981:17; Rogers 1977:171-173). The great secular trend of Tongan history is driven by this rivalry. According to oral tradition, when the 23rd Tu'i Tonga was assassinated in the fifteenth century, his son retained the divine privileges of the Tu'i Tonga but surrendered the effective governance of his kingdom to his younger brother, Takalaua. From that time the government was divided between a "working chief" ( $t u^{\prime} i$ or 'eiki ngāue) associated with the Kauhalalalo cluster of titles and a "most sacred chief" (tu' $i$ or 'eiki toputapu) associated with the Kauhala'uta cluster of titles (Figure 1). The term kauhala'uta means the "bush" side of the road and the term 
kauhalalalo means the "lower" side of the road, most scholars interpreting this as a symboliccum-geographical division between land and sea. While the "sacred chief" enjoyed a great many privileges, the "working chief" was the effective leader, a governor of the people and the land (Ve'ehala, pers.comm.).

The initial "working chief" was the Tu'i Ha'atakalaua (Figure 1). However, by the seventeenth century, the Tu'i Kanokupolu had displaced the Tu'i Ha'atakalaua as the "working chief", the Tu'i Tonga continuing as the "most sacred chief". These diarchic arrangements (Biersack 1990a; Valeri 1989, 1990a) were superseded in the nineteenth century, when Tāufa'āhau, a usurper, ${ }^{2}$ unified the archipelago, took the name King George Tupou, and substituted for the diarchy of the past a constitutional monarchy. Since Tāufa'āhau was heir to the Tu'i Kanokupolu title, the Kauhalalalo had in effect displaced the Kauhala'uta.

As I shall argue here, these hierarchical transformations were underwritten by the complexity of Tongan ranking. A person acquires political status through his or her father but personal status through his or her mother and is thus complexly and often contradictorily positioned within a social and political field. Over against a $h a^{\prime} a$ system of titles, egocentric kindreds or kāinga (Kaeppler 1971) have their own social and political force. Considering such complexity, Goldman argues that though the "structure is stable" in the sense that its "two coordinates" endure over time (ibid.:304), the "points on the coordinates" that is, the rank order of particular historical actors - "are unstable" (ibid.). “... persons who are ambitious cannot change the absolute laws of genealogical rank .... The structure does, however, allow for shifts in power relationships, offering several leverage points for such shifts" (ibid.:304-305).

Together with Bott's Tonga at the Time of Captain Cook's Visits, Goldman's analysis offers a basis for rethinking Tongan society in historical terms, albeit without precluding structural analysis. Here I develop a post-Durkheimian sociology of Tonga based on a combination of structural analysis and historical investigation. The first section provides the structural analysis. The remainder of the paper exploits this analysis as an instrument of diachronic investigation. In the concluding section I draw the lessons that Tongan history has to teach about the relationship between structure and event, the synchronic and the diachronic. My main claim is that Tongan structure becomes operational only in and through Tongan élite marriage practices and that the Tongan ramage is a product of these practices and their dynamics. In the course of developing the argument, I take up the issue of women's status and position in Tonga - a topic that is unavoidable given the array of synchronic and diachronic material this paper surveys and the importance assigned to marriage in it. ${ }^{3}$ 


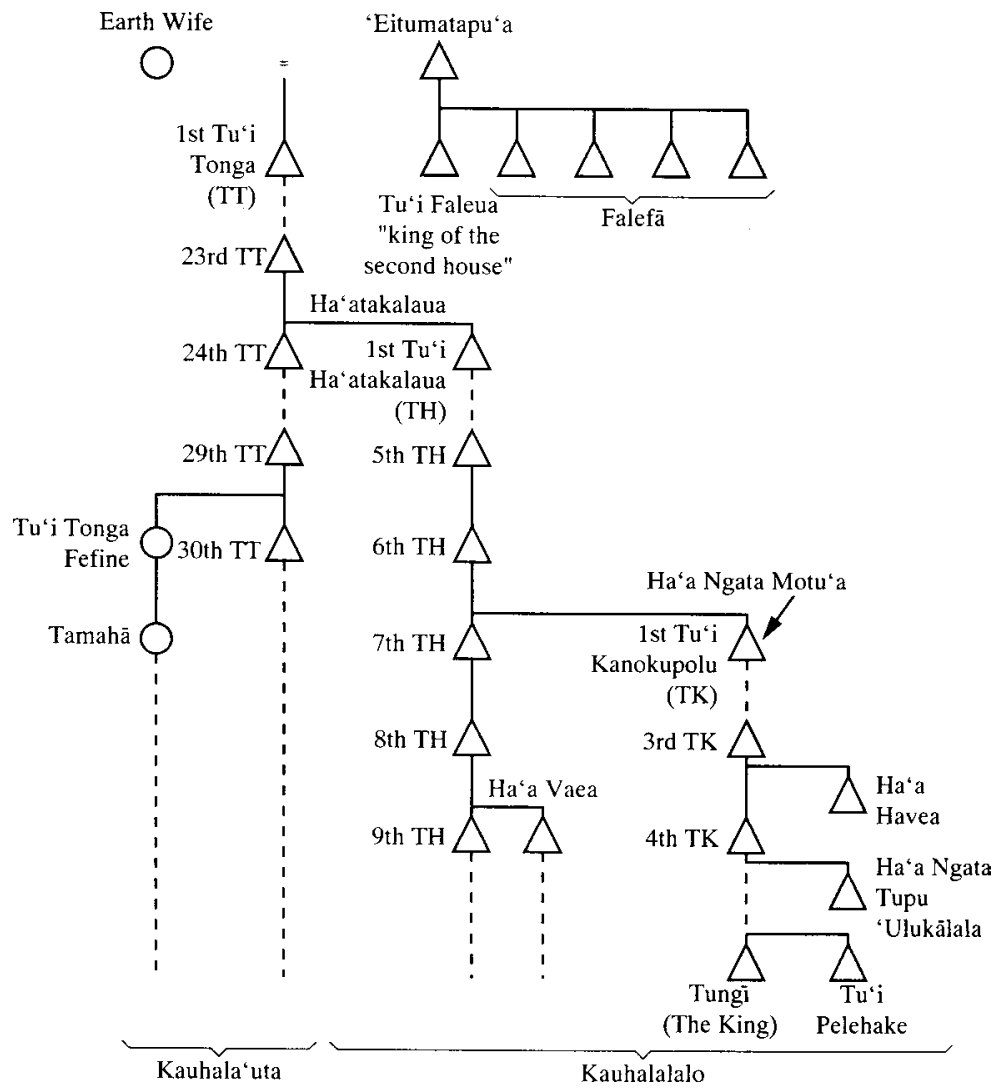

Figure 1. A simplified representation of the Tongan title system (adapted from Biersack 1982 [1974]:197 [Figure 1]).

\section{Complexities of Rank: Blood and Garland}

Traditionally and still today, Tonga sustains two ranking systems (Biersack 1982 [1974], 1990b, 1991a; Bott 1981, 1982; Goldman 1970:449-459; Kaeppler 1971; Rogers 1977), each operating in its own context and cultural domain. The kāinga (kinship, kindred) system rank orders persons as persons and as they participate in kindreds, while the $h a^{\prime} a$ system rank orders titles and their holders according to an agnatic calculus: elder brother:younger brother: ' eiki [or chiefly rank]:tu'a [or commoner rank]::high:low. ${ }^{4}$ Within the title system, at least in theory, the consanguineal relationship among actual titleholders is immaterial. What matters is the genealogical proximity of eponymous ancestors to an apical ancestor: 'Aho'eitu, the father of the first Tu'i Tonga (Sahlins 1958:ch.1). Also, whereas eligibility for office is unilineally conferred, personal rank is not only unique but is bilaterally rather than unilaterally and unilineally determined.

Within the context of the käinga, sister and sister's children outrank brother and brother's children. Thus, in life crisis ceremonies women and their children 
are the ranking figures (Biersack 1982 [1974]; Bott 1972, 1981:18-20; Kaeppler 1971; Rogers 1977). The highest position in such ceremonies is the fahu position, which is usually occupied by a sister's child or a father's sister's child. A position of honour, the fahu receives the best of the valuables distributed in such ceremonies.

In the past sororal hegemony had its most dramatic expression in the extraordinary status accorded the sister of the Tu'i Tonga as the "female" Tu'i Tonga or Tu'i Tonga Fefine. The status of the Tu'i Tonga Fefine and that of her eldest daughter, the Tamahā, were conferred within the kāinga of the Tu'i Tonga rather than within the $h a^{\prime}$ ' system. Of the Tu'i Tonga Fefine, John Thomas, the first continuing Methodist missionary in Tonga, wrote that the position gave "her no power or authority, but she is raised by it, and greatly honoured" (Thomas 1879:15). The Tu'i Tonga Fefine was married to a chief of the Ha'a Fale Fisi, the "ha' $a$ of the house of Fiji", a line of foreign provenience (Figure 1). The foreign paternity of the Tamahā or eldest daughter of the Tu'i Tonga Fefine meant that, although the Tu'i Tonga Fefine's children had the highest possible personal rank through their mother and outranked their mother's brother, the Tu'i Tonga, their rank in the $h a^{\prime} a$ or title system was inferior to his. Chiefs of a foreign line, they constituted no serious political threat to the paramount (cf. Sahlins 1976:42).

In an idiom of "garland" (kakala) (or "name" [hingoa]) and "blood" (toto), Tongans themselves distinguish between the person and his or her rank vis-à-vis kin, on the one hand, the title and its rank, on the other. The title is metaphorically a "garland" the titleholder wears. In contrast, personal rank is "blood" rank, the rank of the "body". A key aspect of the blood/garland distinction concerns the kind of power associated with each kind of rank. The sister and her children, vis-à-vis the brother and his children, exercised power over individual and biological life (ibid.), while the power of the titleholder was a public power exercised over macrosocial geopolitical units, the village and the estate ( tofi $^{\prime} a$ ) on which a village or multiple villages formed. Sororal power was manifested most dramatically in a father's sister's cursing power, which placed organic life at risk, while the latter was manifested in the juridical authority of a chief.

The distinction between ha'a and käinga rank, "garland" and "blood", is gendered. The rank acquired through women is personal while the rank acquired through men is the impersonal public rank of title and office (Biersack 1982 [1974], 1991a; Rogers 1977). Thus, while paternal rank is a factor in determining a child's personal rank, the blood of the mother is more important than the blood of the father (Bott 1981:19; Gifford 1929:113; Marcus 1977:227, n.8, 1980:89; Spillius n.d., ch.5, BSP 4/3/31 $)$ ). "If an aristocratic woman and an aristocratic man of roughly equivalent rank marry commoners of low rank, the children of 
the aristocratic woman will have much higher rank than the children of the aristocratic man" (Spillius, "Kinship and Ha'a in Tonga", BSP 5/6/5-6). It follows that the fount of aristocratic blood is feminine. "To be 'aristocratic' ... means to be descended from the Tu'i Tonga Fefine or the Tu'i Tonga" (Bott 1982:61) or the Tamahā (Bott 1981:36; see Rogers 1977:170-173). Of a child whose high rank depends primarily on the mother it is said that the child is tama tu' $u$ he fa', "child standing on the mother" (BSP 17/6/n.p.) or "child standing in the mother" (Collocott and Havea 1922:118).

Whereas women and their children effectively dominate the contexts governed by personal rank (life crisis ceremonies), "their ascendancy was supposed to be confined to the realm of rank" (Bott 1982:76). Titleholders, however, assumed the command of particular villages and districts and all the people living therein; and it is men rather than women who are associated with the title system. Except in rare cases, titleholders were and are male.

Men have authority (pule) over their younger brothers and over their children - also over their wives. They control access to land and titles; they control and organise economic affairs. Reciprocally, men owe allegiance, subservience, respect, and tribute to their fathers and older brothers, real and classificatory. Sisters, however, have higher rank than brothers, even though they have no secular authority over them. They are more 'eiki than brothers, but have no pule over them (Bott 1982:58).

Similarly, Garth Rogers refers to "the ideology that the 'father's side' of the family has the pule over the children and not kāinga ' $i \mathrm{fa}$ ' 'the mother and her immediate relatives' ... 'father' is normally considered the head of the household with pule over its members ..." (1977:159). He goes on to observe - drawing on remarks made by Tupou Posesi Fanua, a well-known authority on Tongan culture - that the "rights of a fahu at a wedding, first-birthday, or funeral are symbolic and decorative but not political; in fact, Tupou Posesi said that "the fahu have no say in anything; they are not the pule" (ibid.:168). ${ }^{6}$ Moreover, the idioms in which the relationship between and among titles is couched - as father and son or older and younger brother (Biersack 1982:196) — is agnatic. It is said, I am told ('Okusitino Māhina, pers.comm.), that "from women blood flows" ("ko e fefine ko e fakahokohoko toto") but "from men titles flow" ("ko e tangata ko e fakahokohoko hingoa"). This is not to deny that men no less than women had personal rank and that men no less than women functioned as fahu on particular occasions. Since sister's children outrank brother's children, men outrank their mother's brother and his children and have the same käinga or kinship superiority toward them that the sister enjoys vis-à-vis the brother or the father's sister enjoys vis-à-vis the brother's children. 
Public authority is acquired through titleholding; and no matter how high the rank of a particular person, rank could not be translated into command without the bestowal of a title. Elaborating upon Bott's (1981, 1982), Rogers' (1977) and Kaeppler's (1971) work, as well as my own early work (Biersack 1982 [1974]), I have argued that title and the authority that attaches to it are inherently impersonal - authority emanates from the office rather than the person and all titleholders are the same - while rank is inherently personal, an attribute of bodies (Biersack 1990b, 1991a). Thus, the Tu'i Tonga Fefine, second in rank only to her own children, had no heir. Instead of being succeeded, the Tu'i Tonga Fefine was transcended - by a daughter who outranked her: the Tamahā or "most sacred child". A daughter of a chief of the Ha'a Fale Fisi (Figure 1) and the Tu'i Tonga Fefine, the Tamahā was fahu to the Tu'i Tonga.

In distinguishing the two ranking systems, Bott dwells in particular on one Lātūnipulu, who as Tu'i Lakepa of the Ha'a Fale Fisi (Figure 1) had a relatively low status within the title system but who as sister's son or fahu of the Tu'i Tonga had exceptionally high personal status. In meeting Lātūnipulu in 1773, Captain Cook was immediately impressed with his apparent power and prestige. Cook "saw that he was a man of some consequence by the extraordinary respect paid him, some when they approached him fell on their faces and put their heads between his feet and what was still more no one durst pass him till he gave them leave" (from Cook's journals; quoted in Bott 1982:16-17). Lātūnipulu's prestige, a matter of blood and not title, stemmed from his mother, the Tu'i Tonga Fefine; ${ }^{7}$ and in this was feminized. It was (and still is) possible for a man to have high personal rank but no title; a man could be, in the local idiom, "chiefly in body" (sino ' $i$ 'eiki [Bott 1981:10-11] or an aristocrat without being appointed to title ('eiki fakanofo, "chief who has been installed") (ibid.).

There is a sense in which title rank is inferior to blood rank, the rank being an attribute of the title but not the person. A titleholder having no royal blood is said merely to wear a garland ("Discussions with Queen Sālote" 1:50; hereafter referred to as "Discussions"). "The title [or] 'garland' (kakala) can be taken away [but the] 'blood' (toto) is one's own for ever" (Bott 1981:38; see also "Discussions" 1:50; Marcus 1980:18-19). "It was typical for titles to be disdained", Marcus observes (ibid.:61). High ranking chiefs "frequently passed them on to younger siblings, adopted children, or other persons of lower kin rank" (ibid.); and James Spillius writes that "very high ranking [male] aristocrats considered it lowering to have a title, and were known by their personal names rather than the name of their titles. Some had no titles. Titles meant political obligations; high rank meant deference from everyone" (Spillius, "Kinship and Ha'a in Tonga", BSP 5/6/6). Even though Lātūnipulu was Tu'i Lakepa, "he rarely used the title; ... the very great 'eiki (like Lātūnipulu) were scornful of titles, which they considered to be appropriate to lesser ... chiefs" (Bott 1982:60). 


\section{Affinal Politics}

Although commoners may marry willy nilly for romantic reasons, élite marriage is regulated. Partners marry class endogamously and by way of assuming public responsibilities. Among aristocrats there is a preference for aligning the two kinds of status. Through mother's brother's daughter marriage, a man could reinforce his title status with fahu status. From the fifteenth century on, the leader of the Kauhala'uta side of the title system took the eldest sister of the chief directly inferior to him as his moheofo or principal wife, each Tu'i Tonga being at once holder of an "older brother" or "father" title and fahu to the holder of a "younger brother" or "son" title (Biersack 1982 [1974]; Bott 1981:55-58, 1982:59, Fusitu'a 1976:10; Lātūkefu 1974:3). Among high aristocrats who succeed to title, the preference for status congruity is clear. Heirs have occasionally declined a title because they believed themselves to be insufficiently aristocratic in blood to merit it. Agnatic heirs may step aside to enable sisters' sons to succeed lest their inferior blood tarnish the title ("Discussions" 1:57). Conversely, if their personal rank was too high for the title, as already discussed, they might spurn it and remain untitled.

A well-known example of this preference for congruity across the two status fields concerns the Tuita title. Tuita Kahomovailahi had two wives. The ranking one, Tamahā Lātūfuipeka, gave her cousin Naukovi, of much lower blood, to Tuita Kahomovailahi as a secondary wife. ${ }^{8}$ Naukovi bore Po'oi Niutupu'ivaha, while the Tamahā bore Makahokovalu. As the first-born son of the principal wife, Makahokovalu was the clear heir to the Tuita title. Yet this title was relatively low - not even a chiefly title but a matāpule or ceremonial attendant title. Through his mother, Makahokovalu had access to the Tu'i Lakepa title. The previous Tu'i Lakepa had been the son of Lātūnipulu mentioned earlier (Bott 1982:73). This son had died without issue, placing the title at risk. Makahokovalu rescued the situation by assuming the Tu'i Lakepa title as Lātūnipulu's daughter's son and fahu ("Discussions" 2:285; see also ibid. 1:175). "None of the patrilineal heirs [those who were from agnatic collateral branches] could compare to him in rank, and he just went and had himself appointed without even having a meeting of the male heirs" (Bott 1982:73) (see Figure 2). ${ }^{9}$

Personal rank was among the criteria employed in making succession decisions. It came into play again in the next generation, with the appointment of a new Tuita. Makahokovalu's failure to assume the Tuita title opened the door to Po'oi, the son of the secondary wife, to succeed - which he did (Figure 2). Po'oi's son was then heir apparent. Yet it was not Kahomovailahi but Makahokovalu's son who succeeded to the Tuita title. Makahokovalu had married the daughter of Laufilitonga, the last Tu'i Tonga ("Discussions" 2:285; see also ibid. 1:175). In view of the exceptionally high rank of the resulting son, 'Ulukivaiola, Po'oi's son stepped aside to let 'Ulukivaiola succeed (Figure 2) 
(Tupou Posesi Fanua, pers.comm.; see also Fanua, n.d., and "Notes on the Pongipongi of Tu'i Vakanō, 4th July 1958", BSP 13/4/3).

It was in the interest of those at the margins of the political system to use marriage to elevate their status in a bid for public recognition and prestige. As Bott has observed, junior lines agitated against their seniors by marrying the women of the senior line (Bott 1982:62), appropriating for themselves, for example, the very sororal blood that the Tu'i Tongas preferred to bestow upon foreign chiefs to avoid empowering rivals. Such practices are sometimes described in terms of theft or seizure, suggesting the agonistic character of the practice. "Wives of high rank were sometimes seized by other men who wanted suitable mothers for their children" (Spillius n.d.: ch.5, BSP 4/3/84).

Tāufa'āhau, the usurper who dominated the nineteenth century, was himself "only a little tiny bit 'eiki [or chiefly]" ("Re Feudalism", BSP 22/3). Laufilitonga, heir apparent to the Tu'i Tonga title, though not by any means Tāufa'āhau's only adversary, was the most prestigious one. A woman could not be moheofo or principal wife of the Tu'i Tonga unless she was a virgin (Ve'ehala, pers.comm.). Wanting to deprive the Tu'i Tonga of an heir, Tāufa'āhau found a pretext for sending his sister, Halaevalu Mata'aho, to another chief — the Tu'i Ha'ateiho of the Ha'a Fale Fisi ("Discussions" 1:53), who, like the Tu'i Tonga, was on the Kauhala'uta side - to whom she bore a child. When she was finally sent to the Tu'i Tonga, she was no longer suitable as moheofo and could not produce an heir. $^{10}$

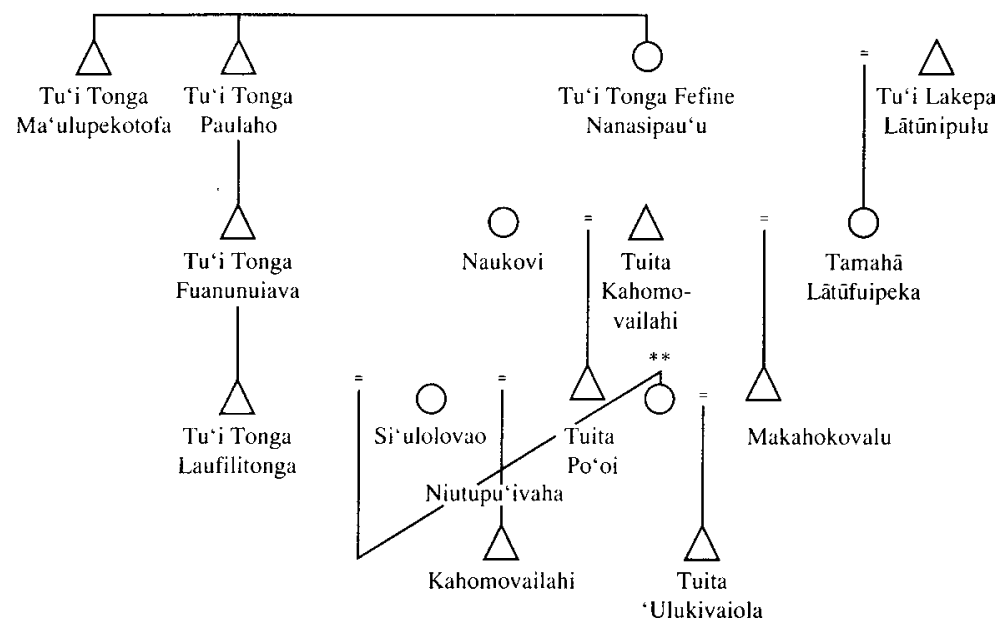

Figure 2. Succession to the Tuita title.

* Compiled from Bott (1982:12) (Figure 1), ibid.:32 (Figure 4), ibid.:74 (Figure 9), and ibid.:154 (Figure 31(b); BSP 13/4/3; Fanua (n.d.).

** Bott (1982:74) (Figure 74) lists this woman as Fatafehi Fangaafa. However, she is listed as Fatafeni Fanga'ofa in Bott, "Notes on the Pongipongi of Tu'i Vakano, 4 July 1958, BSP 13/4/3. 
The withholding of Halaevalu was part of a larger initiative that culminated in the Constitution of 1875, with its renovation of the title system and related developments. Though the Tu'i Tonga title was never abrogated, after the death of Laufilitonga it was not reappointed and effectively lapsed (Lātūkefu 1974:90; Marcus 1980:38). When Halaevalu Mata'aho was finally released to Laufilitonga, she bore him twins, the one Lavinia Veiongo, a woman who subsequently became an important source of Tu'i Tonga blood for the Tupou Dynasty, and the other Kalaniuvalu. Kalaniuvalu was made a nopele by the 1875 Constitution as a representative of the Tu'i Tonga line (Ellem 1981:66; Marcus 1980:38-39). Since the Kalaniuvalu title was created by Tupou I and is appointed by the Tu'i Kanokupolu cum King, it is ipso facto inferior to these two titles, as the Tu'i Tonga title was not ("Discussions" 2:351). As a result, Kalaniuvalu cannot be buried in the special tombs or langi reserved to the Tu'i Tonga (ibid.). The marriage between Halaevalu and Laufilitonga was therefore crucial to producing an heir for a title that could not be vested with authority in the old system but that took its place in a Tupou-dominated constitutional monarchy. It was also crucial for setting the stage for an appropriation of Kauhala'uta blood by the Tupou Dynasty later, when Tupou II married, a chapter of Tongan history reviewed below.

Tāufa'āhau made the complementary move of capturing as his own wife one of the Tu'i Tonga's wives, Lupepau'u (Cummins 1980:41, 74; "Discussions" 1:61; Queen Sālote, "Ko e Ngaahi Ha'a 'o Tonga", BSP 11/2/15; cf. Ellem 1981:66). Tāufa'āhau was to have married Lupepau'u's younger sister; but when Lupepau'u attended a wedding in Tāufa'āhau's area, he claimed her for himself (Collocott Papers, MS 1058:1, 19). There was no retaliation - either because Laufilitonga was no match for Tāufa'āhau (he had already lost the decisive Battle of Velata to him) or because it was considered "beneath the dignity of a chief to quarrel over women" (Bott 1982:139).

Marriage was not just a status game. It could be and was used to develop political resources through the prerogatives of blood. A brother owes his sister and her children support.

The mother's side consists of a set of brothers and brother's children to whom she and her children are superior. This principle was of great importance in the traditional political system. It meant that a leader could always expect support from the groups of his mother and his wives, also from the group of his mother's mother. It meant that he had to give support to the groups into which his sister, his sister's daughter, and his father's sister married, always assuming they had children (Bott 1981:19; see also Bott 1982:62-63). 
Typically this support consisted in provisioning the sister and her husband with food, which meant that a leader could acquire the wherewithal to support a large retinue through his affinal and matrilateral ties. These ties, moreover, could be used to augment this retinue. Since "[t]raditionally the main basis of political power was the ability to build up and lead a local group" (Bott 1981:9), a polygamist could encourage his wives and relatives to live with him, thus expanding his group (Spillius, "Kinship and Ha'a in Tonga", BSP 5/6/17) and its labour resources. The kinspeople of a woman who married a chief were often committed supporters of the woman's son by that chief (Bott 1982:132).

Then again, if the wife-giver were himself high in rank but bereft of resources, land, labour, and people could flow in the opposite direction, from wife-taker to wife-giver. For example, when Fusipala, the daughter of the fourth Tu'i Kanokupolu Mataeleha'amea, was given by her brother to an untitled Pelehake leader who controlled a lot of people and land in eastern Tongatapu and was thus powerful, "even though he was not of high rank" (Bott 1982:138), the sister's husband shared his resources with his wife's people and not vice versa. Queen Sālote elaborated upon the husband's reasoning:

The brothers knew that the very fact he was not 'eiki would make him keen to marry a king's daughter, and they wanted to get his support. Normally it is the woman's people who feed and support the husband's people. But in a case of this sort, where the man was powerful but had no title and was not 'eiki whereas the woman was the daughter of a king, the husband's people would support the wife's people and particularly the king (ibid.).

Land no less than labour could be acquired through marriage. As Spillius has written:

There were many cases of inheritance of land through women before the Constitution [1875], when the daughter of a title-holder married a king or some other important title-holder, her father gave her a piece of land to support her and her children. After her death it might be kept by her children or it might be returned, depending on circumstances. In other cases a prominent man, usually the brother or son of a king, married a woman whose father was rich in land but lower in rank. The children of such a marriage inherited the land of his mother's father (Spillius, "Kinship and Ha'a in Tonga", BSP 5/6/8).

Since transfers of land implied transfers of people, titles could be inherited matrilaterally as well as patrilineally. For all "working chiefs" — and all chiefs except the Tu'i Tonga of the diarchic era have been working chiefs (Biersack 1990b) - primogeniture has never been the only discriminator in matters of succession. Multiple criteria were employed in choosing a successor: not only 
birth order but the rank of the mother and the power of matrilateral support, age, experience, and ability - all were factors (Bott 1982:72, 123-124; "Discussions" 1:176). Under these circumstances, it was possible for sister's sons to succeed, particularly if the mother was of very high rank (ibid. 1:177, 180). Sister's son could also succeed if the male line lapsed - as, for example, in the case of Makaholovalu's accession to the Tu'i Lakepa title.

In the resulting shifts in effective control from senior to junior lines, affinity and fahu successions played an important role. In the case of both the Tu'i Ha' atakalaua and the Tu'i Kanokupolu, younger brothers were sent, often without title, to outlying districts, where they married in. In a generation or two, these cadet lines would capture the land and titles of these districts, subordinating these to their senior, who now held the paramount title of a growing ha'a or cluster of titles. In regard to the growth of the Ha'atakalaua in the sixteenth century, Bott tells us that the titles thus accruing to that $h a^{\prime} a$ were "often named after the original son or younger brother of the Tu'i Ha'atakalaua who was sent out in the first place" (Bott 1982:63), the land and the title being absorbed as subsidiary units within that $h a^{\prime} a$. “... local titles used to get swallowed up or forgotten" as new centres emerged, expanded, and were consolidated (Bott 1981:51). ${ }^{11}$ After these cadets had secured local support, land, and title, they intermarried with the national élite to upgrade the rank of their heir, providing a double anchorage for their dynasty, local and national (ibid.:48).

Marriage was also the key to upgrading the title that a line already controlled. Again, Tuita provides an example, for 'Ulukivaiola reverted to the Tuita title to raise the rank of that title ("Discussions" 2:296; Figure 2). Traditionally the Tuita title was a "specialised matāpule" title (Marcus 1980:41, n.27) - a matāpule of the navigator kind; Gifford placed the title somewhere between matāpule and ' eiki in its rank (Gifford 1929:109). ${ }^{12}$ In 1880 Tuita was reclassified as a nōpele or "noble" title, the post-Constitutional equivalent of the chiefly titles of the past (ibid.). In recent years Tuita has held one of the more important ministries of the Tongan government and his son is the husband of the King's only daughter, bestower of the highest ranking blood in contemporary Tonga.

The same is true of the Tu'i Pelehake title. The title is related to a mythic one: the title Tu'i Faleua or "King of the Second House", which a sky god bestowed upon the older brother of the first Tu'i Tonga, 'Aho'eitu (Figure 1). 'Aho'eitu ascended to the sky to find his father, this god 'Eitumatupu'a, whom he had never seen. For various reasons, his older brothers were jealous of him and killed him. 'Eitumatupu'a brought 'Aho'eitu back to life and punished the older brothers by sending them back to earth as 'Aho'eitu's subordinates (Biersack 1991a; Bott 1972; Valeri 1989). Just when the Tu'i Pelehake title originated is not clear; but its origin is related to the marriage between Fusipala, daughter and sister of a Tu'i Kanokupolu and the powerful leader of the Pelehake 
district on Tongatapu mentioned before. Presumably from that time on, the Pelehake line became a close satellite of the Ha'a Ngata Motu'a, the Tu'i Kanokupolu's line; and the Tu'i Pelehake title was "lifted up" (ibid.). Later a Tu'i Pelehake married a daughter of a Tu'i Tonga Fefine ("Discussions" 2:282; see Figure 3). This "lifting" through marriage was symbolically reinforced in the nineteenth century, when the Tu'i Tonga's kava privileges were transferred to the Tu'i Pelehake and the Tu'i Tonga title was allowed to lapse. ${ }^{13}$

Politically crucial, women became the focus of a dynamic factional politics. If a woman married a chief and her brother or father was ambitious, her people would rally around her son as a pretender to the title, even without his being a clear heir apparent to the position ("Discussions" 1:46). The gift of a woman could seal a political and military alliance. For example, when Tākai, a famous warrior, decided to settle his differences with the seventeenth Tu'i Kanokupolu, father of the man who would become King George Tupou I, he offered his daughter in marriage to him. He also supplied Tupouto'a with troops upon request and lobbied the chiefs of the Ha'a Ngata Motu'a and Ha'a Havea (Figure 1) to elect him Tu'i Kanokupolu (Gifford 1929:208; Lātūkefu 1974:21). Furthermore, as the episodes of Tongan history soon to be recounted illustrate, an enemy could be co-opted through marriage.

\section{Twentieth-Century Foundations}

\section{The Tupou Dynasty and Its Early Opponents}

The Ha'a Ngata chiefs (Figure 1) initially dominated the western end of Tongatapu and some of them (Ata, for example, or Ve'ehala) continued to be associated with western (hihifo) Tongatapu (Map 1). The children of the fourth Tu'i Kanokupolu became geographically split, however. Mumui and his descendants were associated with central Tongatapu and the shoreline rather than the lagoon (Ellem 1981:60). Meanwhile, Maealiuaki and his descendants operated out of Hahake, the eastern district (ibid.:62). Historically Hahake is associated with the Tu'i Tonga and the Tu'i Ha'atakalaua (Figure 1), titles that are superior to the Tu'i Kanokupolu title. Hahake's ranking town was $\mathrm{Mu}^{\prime} \mathrm{a}^{14}$ the seat of the Tu'i Tonga. With respect to Hihifo, then, Hahake was a rival centre. Its chiefs "were traditionally opposed to the people of Hihifo ... and regarded the assumption of kingship by the Tu'i Kanokupolu, a Hihifo chief, as an usurpation of the rights of the Hahake chiefs, Tu'i Ha'atakalaua and Tu'i Tonga" (Rutherford 1971:14). Compounding this east-west split on Tongatapu was the north-south split between Vava'u, referred to in poetic texts as tokelau or "north", and Tongatapu, literally "sacred south". Ellem dates the hostilities between the northern group and the southern island from the end of the eighteenth century (1981:62). In the nineteenth century, the principal chiefly name associated with the north was 'Ulukālala (Figure 4) of the Ha'a Ngata Tupu (Figure 1). Over the course of the 
history summarized in this section, the east of Tongatapu (Map 1) entered into alliance with the north of the archipelago (Map 2) and together east and north opposed the centre of Tongatapu. Herein follows a summary of this history.

The close of the eighteenth century was a turbulent era. Maealiuaki had been the 8th Tu'i Kanokupolu, and some alleged he also held the Tu'i Ha'atakalaua title (Bott 1982:14, Figure 3; Campbell 1982:186-187; Ellem 1981:451, Figure 2; see Figure 4). Maealiuaki and his son Mulikiha'amea were associated with the eastern district of Tongatapu, Hahake (Map 1). Mulikiha'amea was also a Tu'i Kanokupolu, though sources disagree about whether he succeeded his father directly and whether he also held the Tu'i Ha'atakalaua title, as his father apparently had. ${ }^{15}$ The principal rivals of the Maealiuaki line would come from central Tongatapu in the person of the chiefs of the Tupou Dynasty, beginning with Mumui (Figure 4). Mumui, the founder, was the 13th Tu'i Kanokupolu (Bott 1982:14, Figure 3) and according to Bott he died two years before Mulikiha'amea died. How did Mumui acquire the Tu'i Kanokupolu title? The answer to this question concerns in part the exploits of one of the best known Tongan women, Tupoumoheofo.

Tupoumoheofo was the main wife or moheofo of the Tu'i Tonga Paulaho and daughter of the seventh Tu'i Kanokupolu and full sister of the ninth Tu'i Kanokupolu. She was also father's sister of an heir to the title (see Figure 4; Bott 1982:14, Figure 3; Gifford 1929:88; Herda 1987:203). There are many accounts of how Tupoumoheofo captured the Tu'i Kanokupolu title. Some claim that Tupoumoheofo secured the Tu'i Ha'atakalaua title for Mulikiha'amea so that she herself could assume the Tu'i Kanokupolu title ("Tonga: A Brief History", BSP 4/5/8-9; "Discussions" 1:44). Still others report that it was Mumui and Tuku'aho (Figure 4) who pressed for Mulikiha'amea's installation as Tu'i Ha'atakalaua so that one or the other could assume the Tu'i Kanokupolu title once he had vacated it (Herda 1987:205, 1988:100) (but see n.15). Gunson, meanwhile, envisions Tupoumoheofo as assuming the title after her brother Tu'i Halafatai, the "effectual ruler" (Gunson 1979:39; see n.18), "retreat[ed] from political life and ... retired to Fiji and Samoa" (Gunson 1979:40; see also "Discussions" 1:44). ${ }^{16}$ However the title became vacant, once it was vacant Tupoumoheofo named herself the successor and installed herself as Tu'i Kanokupolu by sitting with her back against the koka tree in Hihifo that the Tu'i Kanokupolu traditionally leaned against when being installed (Gifford 1929:88). 


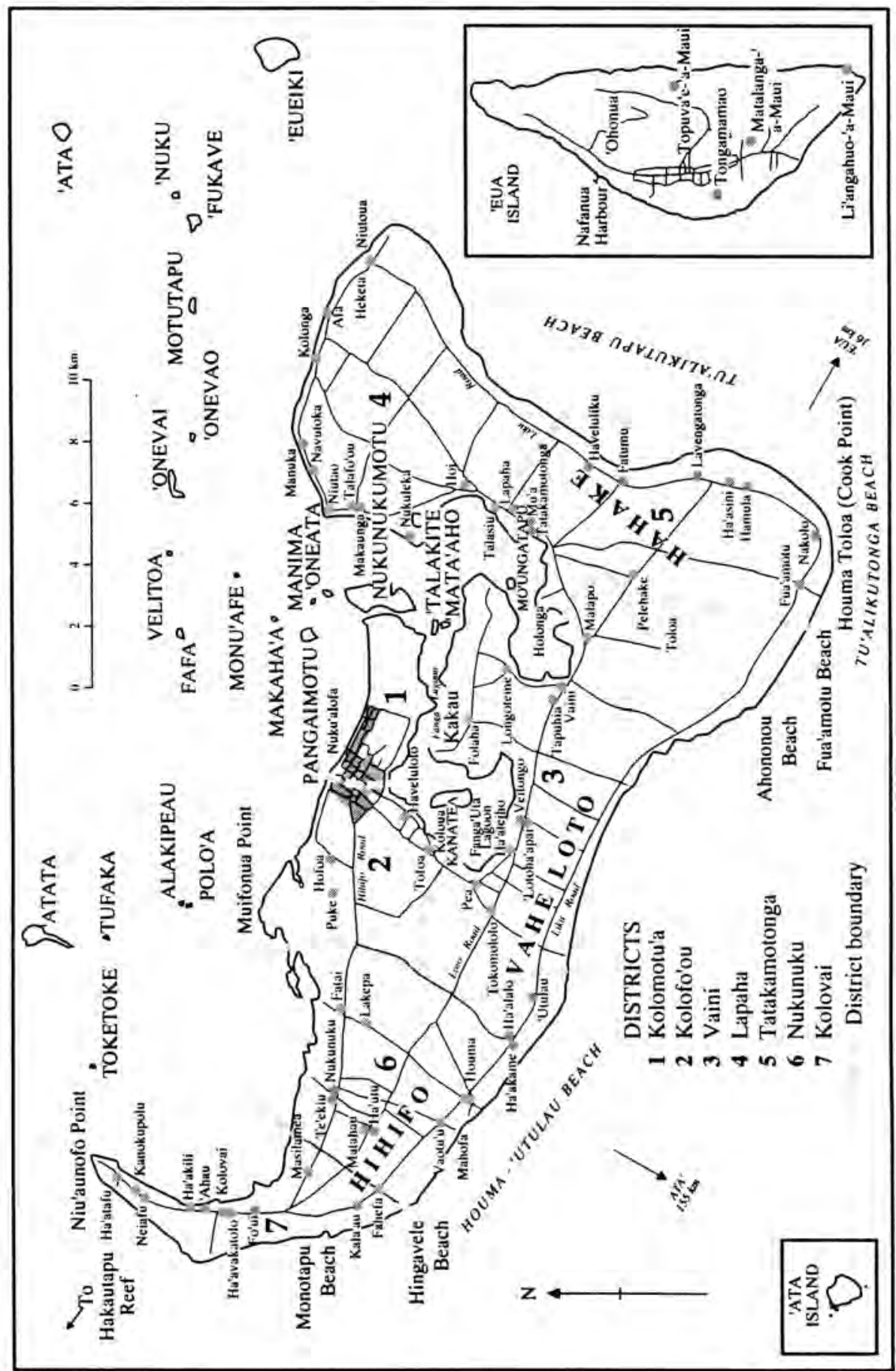

Map 1. Tongatapu. 
What her intentions were is a matter of conjecture. Ellem suggests that her goal in becoming Tu'i Kanokupolu was to pass this title on to her son, Fuanunuiava (Ellem 1981:61), who would eventually contend (Ellem claims [ibid.:62]) for the Tu'i Kanokupolu title in 1797, when Mumui died (see, for example, Dumont D'Urville, 1989:114). Others speculate that Tupoumoheofo hoped to restrain the Tu'i Kanokupolu by uniting the country under the Tu'i Tonga again ("Discussions" 1:60). She could have been responding, among other things, to the failure of Maealiuaki to send his daughters to the Tu'i Tonga but, rather, to send them to men of the Tu'i Kanokupolu line instead (ibid. 1:69) and to the fact of the recent doubling of titles on the Kauhalalalo side, a single person holding both the Tu'i Ha'atakalaua and the. Tu'i Kanokupolu titles (Figure 1). In fact, some claim that she attempted to install her son Fatafehi Fuanunuiava as Tu'i Tonga while her husband was still alive. This occurred, according to Bott and Queen Sālote, at the 'inasi ceremony witnessed by Captain Cook (ibid. 1:44). ('Inasi was the ceremony in which the annual prestation of tribute [also called ' inasi] was made.) ${ }^{17}$ That would have been a victory for the Kauhala'uta side, although Tupoumoheofo could as well have unified the country under the Tu'i Kanokupolu, thus favouring the Kauhalalalo side (Figure 1). ${ }^{18}$ As moheofo of the Tu'i Tonga and full sister to a Tu'i Kanokupolu, Tupoumoheofo was capable of operating across the divide between Kauhala'uta and Kauhalalalo. Whatever her ambitions, Tupoumoheofo's power and office were short-lived, for Tuku'aho, Mumui's son, mobilized an army on Tongatapu and defeated her and her supporters (ibid.); and he followed up this victory by naming his own father, Mumui, Tu'i Kanokupolu. 
Origins, Ancestry and Alliance

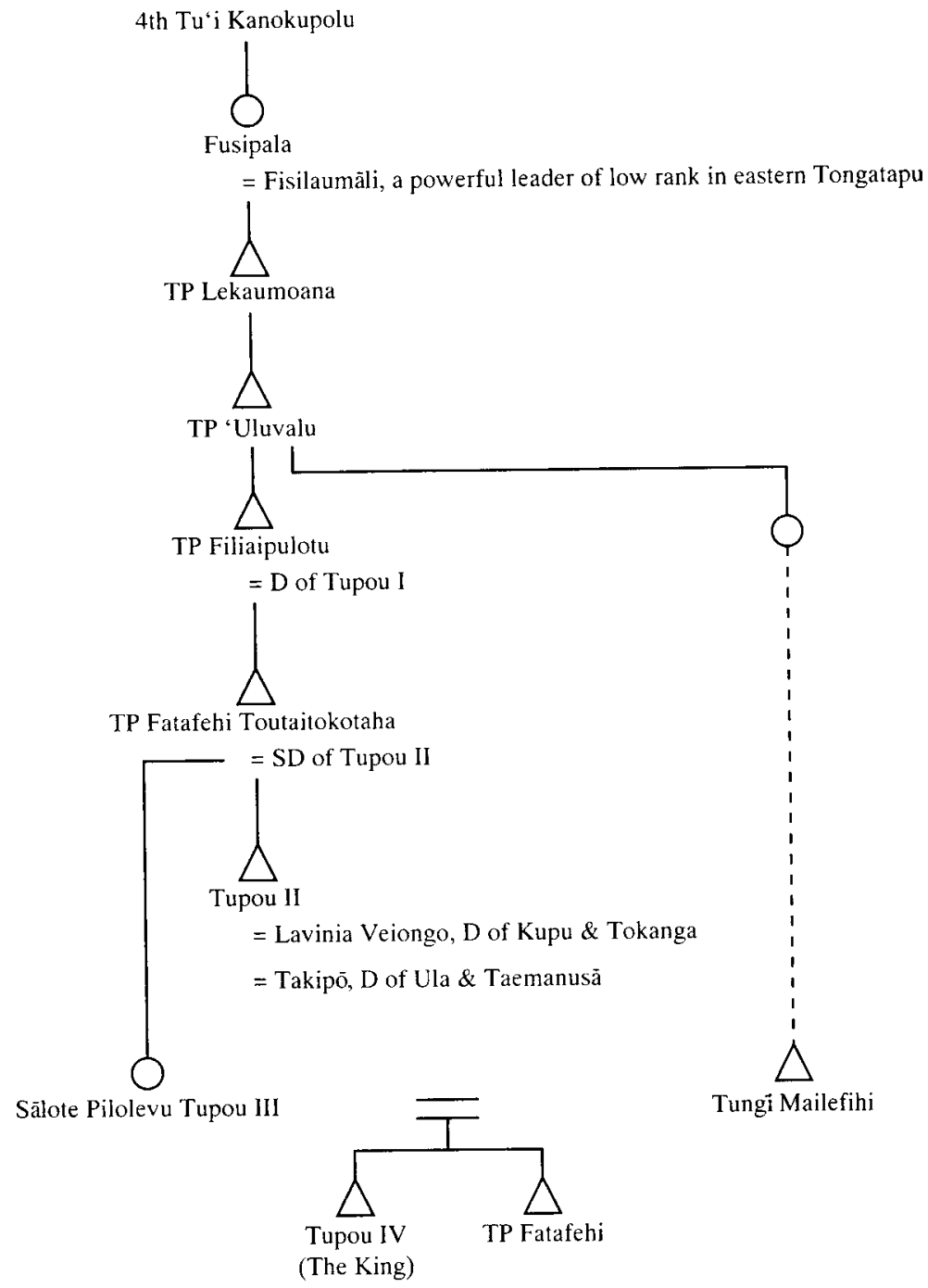

Figure 3. Fusipala and the elevation of the Tu'i Pelehake (TP) title (adapted from Bott 1982:147 [Figure 24]). 


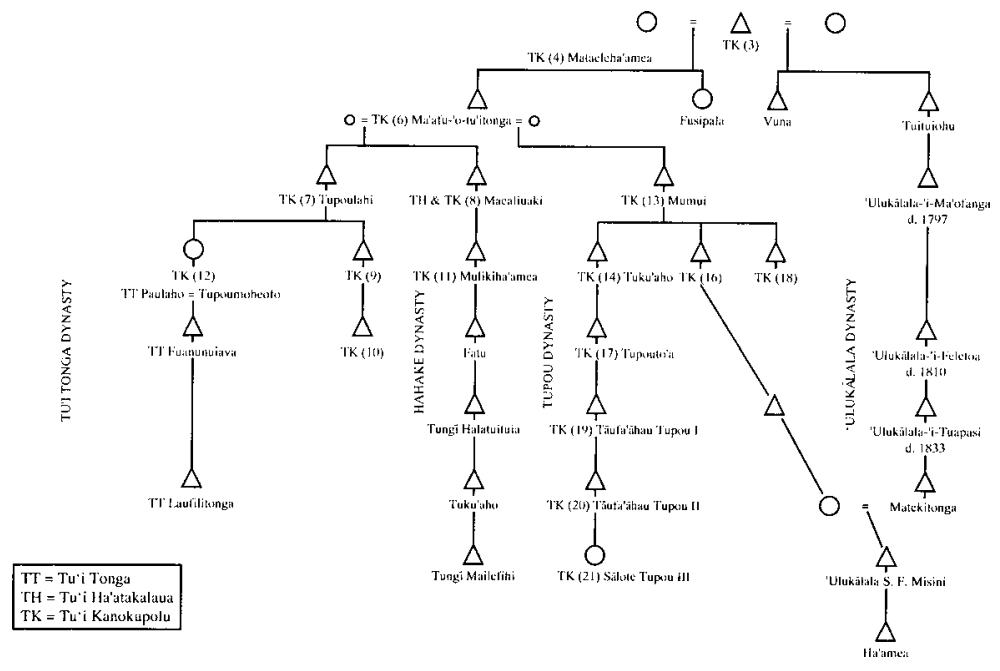

Figure 4 Rival dynastic lines 1780-1938 (adapted from Ellem 1981:451 [Figure 2]).

However short-lived her term as Tu'i Kanokupolu, Tupoumoheofo managed to overturn an achievement of another powerful chiefess, Fusipala. Fusipala has been mentioned before, as the wife of Fisilaumāli, the chief in eastern Tongatapu who was low in rank but powerful. Fusipala was the daughter of the fourth Tu'i Kanokupolu and half-sister of Tuituiohu, founding ancestor of the Ha'a Ngata Tupu, with which the 'Ulukālala title of today is associated (Figure 4) (Bott 1982:140). She was also possibly the wife of the fourteenth Tu'i Ha'atakalua and mother of the fifteenth Tu'i Ha'atakalaua (Bott 1982:138, ibid.:Figure 2, p.13, and Figure 23, p.138). Her son by Fisilaumāli was the first known Tu'i Pelehake (Figure 3). Fusipala was therefore powerful (Herda 1988:93) — so powerful that she was able to depose Vuna Ngata, the Tu'i Vava'u (ibid.; Bott 1982:76; Map 2) and son of the fifth Tu'i Kanokupolu. After deposing him, Fusipala installed Tuituiohu as Tu'i Vava'u, "establish[ing] herself as virtual ruler of Vava'u" (Gunson 1987:159) in the process, though officially the Tu'i Vava'u was Tuituiohu (ibid.; also Bott 1982:76; Herda 1988:93, 110). Since Fusipala could count on the support of her full brother, the sixth Tu'i Kanokupolu, "there were few in Tonga willing to cross her" (Herda 1988:93).

In this initiative, Fusipala was thwarted by Tupoumoheofo, now forced into exile in Vava'u as a result of Tuku'aho's recapture of the Tu'i Kanokupolu title. Tupoumoheofo apparently viewed Tuituiohu's son Fīnau-'i-Ma'ofanga as a rival; and when she assumed the Tu'i Kanokupolu title, she deposed him, restoring the Tu'i Vava'u title to her daughter's husband in the Vuna line (Spillius n.d.; BSP 4/5/9; Gunson 1979:40). She thus overturned the work of Fusipala, who had at least momentarily succeeded in shifting the Tu'i Vava'u title from 
the Vuna to the 'Ulukālala line. It was this daughter's husband that gave her refuge in Vava'u when she was first exiled there (Campbell 1989:153; Gunson 1979:41; Herda 1988:112, 114). ${ }^{19}$

With Mumui's accession, the Tu'i Kanokupolu title was transferred to the Tupou Dynasty and incidentally from eastern to central Tongatapu. When Mumui died in 1797, Tuku'aho despite his reputation for cruelty, was elected to replace him. Some claim that Mumui nominated Maealiuaki's son Mulikiha'amea (Figure 4) rather than his own son Tuku'aho as his successor (Campbell 1982:187, 1989:153; Herda 1988:107), thus tacitly endorsing Hahake or eastern precedence. Bott attributes Tuku'aho's success to the support he received from his matrikin, for his mother was the daughter of Ata, ranking chief of the Ha'a Ngata Motu'a and effective ruler of the Hihifo district ("Discussions" 1:42; Bott 1982:146; see also Herda 1988:108-109; see Map 1).

The deposed Tu'i Vava'u, Fīnau 'Ulukālala-'i-Ma'ofanga (Figure 4), was matrilateral half-brother of Tuku'aho (Bott 1982:142, Figure 29; Gunson 1977: 99-100); and he supported Tuku'aho for the Tu'i Kanokupolu title with the expectation of receiving the Tu'i Vava'u title his father had briefly held. But once Tuku'aho had achieved his goal, he confirmed the Vuna line in that office (Campbell 1989:153; Herda 1988:112), despite the kinship tie. 'Ulukālala-'i-Ma'ofanga died several weeks after Tuku'aho's accession — of disappointment, some claim (Campbell 1989:153; Herda 1988:112) — but not without extracting a pledge from his son 'Ulukālala-'i-Feletoa to avenge Tuku'aho's insult (Campbell 1989:154). 


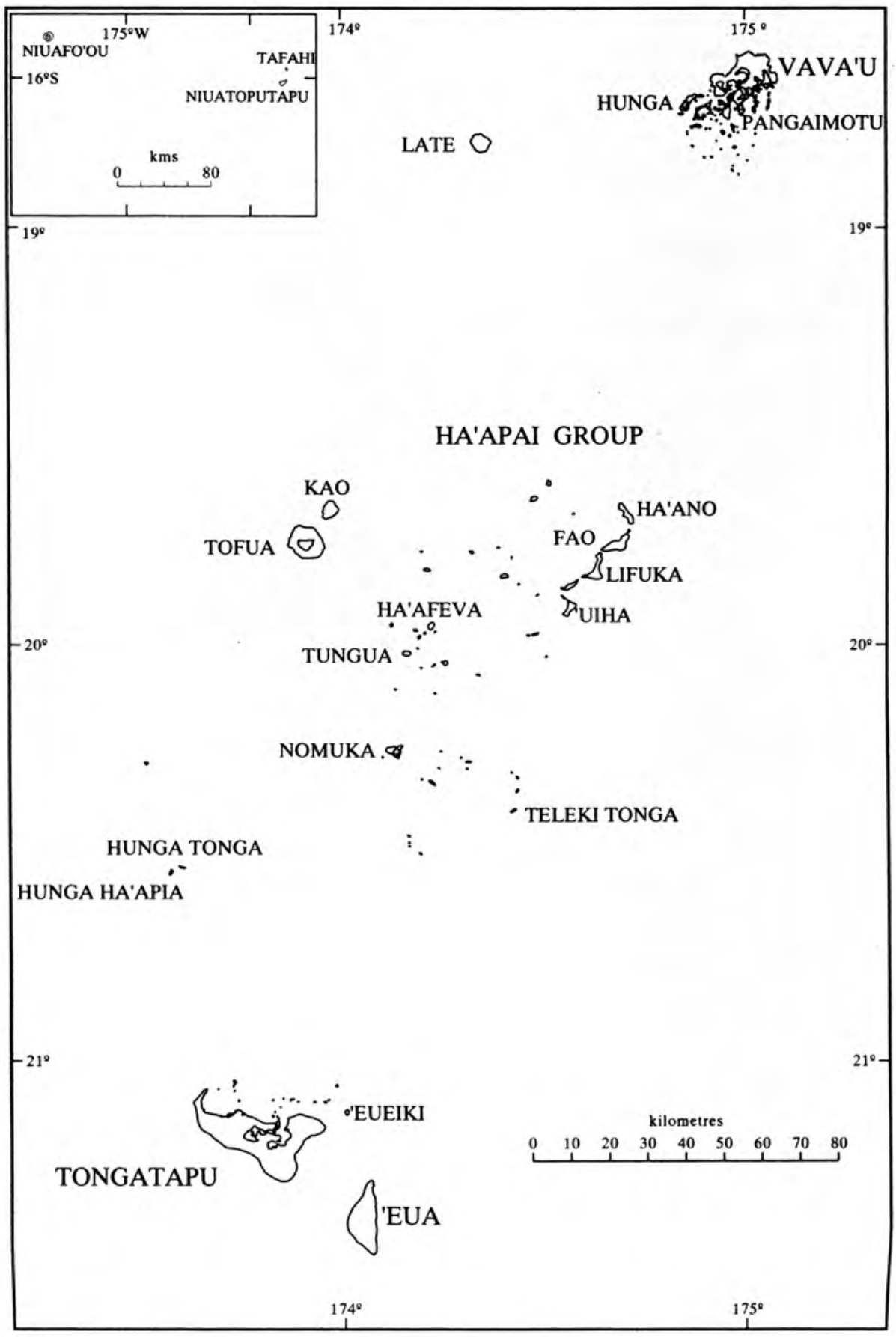

Map 2. Tonga. 
Ostensibly because of his cruelty, though issues of revenge and rivalry unmistakably figured, Tuku'aho was assassinated within two years of his accession. The principal conspirators and their supporters ${ }^{20}$ came from rival branches: Mulikiha'amea from the Hahake Dynasty and 'Ulukālala-'i-Feletoa and his half-brother (Figure 4) (Bott 1982:112, 143; Martin [Mariner] 1981). The matter of Hahake control of the Tu'i Kanokupolu title appears to have had some saliency (Campbell 1989:154; Herda 1988:113-114), yet the anti-Tuku'aho faction was in fact led by 'Ulukālala-'i-Feletoa. In this venture, Mulikiha'amea had two other important allies. One was Fuanunuiava, Tupoumoheofo's son. Mulikiha'amea and Fuanunuiava jointly directed troops marshalled to fend off the expected revenge attack (Campbell 1989:155; Thomas n.d.:2, Book 4, p.256). Tupoumoheofo was herself an ally. Though in Vava'u, Tupoumoheofo was 'Ulukālala's enemy, she was sufficiently outraged by Tuku'aho's appropriation of the Tu'i Kanokupolu title that she was willing to make common cause with 'Ulukālala - some even claim, actively instigating the assassination of Tuku'aho (Lātūkefu 1974:15; Gunson 1979:29; Herda 1987:206). In the civil war that followed the assassination, Tonga was split along geographical as well as dynastic lines: seeking revenge for Tuku'aho's death, Hihifo and central Tongatapu opposed Hahake, Mu'a, elements of the Ha'a Fale Fisi (Figure 1), and the 'Ulukālala Dynasty of the north v. the south (Maps 1 and 2; Herda 1988: 114). There appears then to have been a three-way alliance among those the Tupou Dynasty had in one way or another displaced: the Hahake Dynasty, the 'Ulukālala line, and the Tu'i Tonga. ${ }^{21}$

As the nineteenth century wore on, the schism between Hahake and northern groups, on the one hand, the Tupou Dynasty, on the other, would be played out as a confrontation between Tāufa'āhau, Tuku'aho's son's son, and Tungī Halatuituia, Mulikiha'amea's son's son (Figure 4); and the 'Ulukālalas would continue to demand a Vava'u title.

\section{Tungī Halatuituia}

Though the Tu'i Kanokupolu title was retained by the Tupou Dynasty, and the Tu'i Ha'atakalaua title was no longer appointed, the Hahake Dynasty continued to aggrandize power in eastern Tongatapu. Mulikiha'amea's son, Fatukimotulalo, who based himself at Mu'a, was an ally of Fīnau 'Ulukālala-'i-Feletoa (Gunson 1979:44) and was also the host of the first Wesleyan Methodist missionary in the archipelago, Reverend Walter Lawry (Lātūkefu 1977:115). Despite Fatu's early association with missionaries, he resisted conversion, dying "an unrepentant pagan" ("Tonga: A Brief History", BSP 4/5/36). Fatu settled down in Mu'a, where he was recognized as a local leader, despite the fact that he held no title. ${ }^{22}$ His first wife was the daughter of Tu'i Kanokupolu Mumui and the patrilateral half-sister of Tuku'aho (Bott 1982:88). The mother of this half-sister outranked 
Tuku'aho's mother; and this, together with the fact that sisters always outrank brothers, meant that her child outranked Tuku'aho's son's son, Tāufa'āhau ("Re Feudalism", BSP 22/3).

Tungī Halatuituia was the son's son of a Tu'i Kanokupolu, and he was the son's son's son (if not the son's son [see n.15]) of a Tu'i Ha'atakalaua. As discussed in the previous section, his father's father, Mulikiha'amea, had made common cause with 'Ulukālala in assassinating Tuku'aho, Tāufa'āhau's father's father. However, the Tu'i Ha'atakalaua title had now lapsed and a collateral branch of the descendants of the fourth Tu'i Kanokupolu had captured the Tu'i Kanokupolu title (Figure 4). Through his father's marriages Tungī garnered resources and strengthened his claims to high title. Tungī would eventually base his claim not only to the Tu'i Kanokupolu title but to kingship itself on his descent from Tuku'aho's half-sister, for Tungī's strongest claim to these titles was arguably through his mother's mother ("Re Feudalism", BSP 22/3; Fusitu'a 1976:17). Fusitu'a speculates that it was Tungī's high birth as a hako' $i$ fefine or descendant of a woman that encouraged Tāufa'āhau, now King George Tupou I, to bestow 'Ana Seini, the daughter of his half-sister Halaevalu Mata'aho, on Tungī in 1853 (ibid.), thus reinforcing existing ties between the Hahake and the Tupou dynasties (see Ellem 1981:67). But Tungī was never firmly in Tāufa'āhau's camp. According to one missionary observer, Tungī nurtured "very lively expectations" of a reversal of fortunes and a coming to power as the descendant of the last Tu'i Ha'atakalaua (Cummins 1980:118).

Tupou I ruled as the first constitutional monarch and as author of a number of codes, one of the most important being the Emancipation Edict of 1862. In effect, the Edict, promulgated by Tāufa'āhau in a plenary meeting of chiefs and to some degree against their will, released commoners from traditional obligations. In theory chiefs could no longer require that their people work for them. Tung $\overline{1}$ was among those chiefs who opposed the reforms, viewing the Emancipation Edict "as but another move to strip the chiefs of their privilege, and of their source of labour and livelihood" (Fusitu'a 1976:18).

He also led the opposition in Parliament to Tupou I's choice of successor (Ellem 1981:84; Fusitu'a 1976:18). Everything that made Tungi eligible to succeed to the Tu'i Kanokupolu title also made his heir eligible. Not only was Tungi the son's son of a Tu'i Kanokupolu but his mother's mother was the sister of the assassinated Tuku'aho (Fusitu'a 1976:17), and his personal or "blood" status was therefore high. When Tupou I bestowed upon him his adopted daughter 'Ana Seini Tupou Veihola in 1853, he elevated Tungi even further in importance if not status. 'Ana Seini was the great granddaughter of the Tamahā Lātūfuipeka and much higher in status than Tāufa'āhau himself ("Re Feudalism", BSP 22/3), and with this marriage the superiority of Tungī Halatuituia's heir to any heir 
that Tāufa'āhau could produce was assured (Fusitu'a 1976:17-18). Tungī also had symbolically significant holdings: "the powerful and second part of the ancient town of $\mathrm{Mu}^{\prime} \mathrm{a}$, Tatakamotonga, as well as a great part of the more populous district of Hahake" (ibid.:18; see Map 1); and despite Tungī's father's lack of title Bott refers to Tungī's father, Fatu, as "the ruler of Mu'a" ("Re Feudalism", BSP 22/3).

Despite Tungî's credentials, the Constitution of 1875 named as Tupou I's heir a son by a secondary wife. Furthermore, Ma'afu, the son of the eighteenth Tu'i Kanokupolu, and his heirs, not Tungī and his heirs, were named to succeed Tupou I in the event that his own line should fail. The same legislation awarded him the newly created title Tungī, which supplanted the Tu'i Ha'atakalaua title (Bott 1981:22; Gifford 1929:84; Marcus 1980). The Constitution had replaced the Tu'i Tonga with the Kalaniuvalu title, a title that was appointed by the King and that was ipso facto inferior to the royal title. By the same token, whereas the Tu'i Ha'atakalaua title was superior to the Tu'i Kanokupolu title, Tungī, a position created by monarchical fiat, was inferior to the royal title (Gifford 1929:84). When Ma'afu died in the early 1880s, Tupou I attempted to mollify Tungī by replacing Ma'afu with Tungī and his heirs (Ellem 1981:94; Fusitu'a and Rutherford 1977:175, Rutherford 1971:139-140). ${ }^{23}$ But, as events were to show, Tungī was hardly appeased.

The focus of Tungī's opposition became an expatriate named Shirley Waldemar Baker, principal architect of King George's constitutional monarchy, at least as it existed on paper. As if to add insult to injury, Tungī was passed over for the Premiership and Baker was named Premier instead in 1880 (Rutherford 1971:111). In my reading of the events of this period, opposition to the King was often masked as opposition to the white papālangi foreigner; and agitation against Baker was simultaneously, though unspokenly, agitation against the King. Baker's arch papālangi rival, the Reverend J. Egan Moulton, attracted elements of the antiroyal faction (see Cummins 1980), thus marking the other end of a field that was largely polarized through national contestations.

The 1880s offered several dramatic settings for Tungī's opposition; and in these contexts, the coalition that was already in place at the end of the eighteenth century resurfaced. The first was the series of events stemming from the actions of a group of minor chiefs and matāpule who stood to lose most from Tupou I's reforms (Rutherford 1977:165). Though Baker was the particular target of the group that convened at $\mathrm{Mu}^{\prime}$ a to oppose recent legislation failing to honour the customary land rights of this group, opposition to Baker was inseparable from opposition to the King. Tupou I certainly seems to have seen things that way, for he viewed every anti-Baker initiative, including those associated with what Baker pejoratively dubbed the Mu'a Parliament, as acts of rebellion. 
The Mu'a group entered into coalition with nopele titleholders who had their own reasons for opposing Tāufa'āhau — in particular with Tungī and the Tu'i Pelehake. Though Tupou I ordered Tungī to suppress the activities of the Mu'a group, Tungī defied him and sided with the dissidents, most of whom were either Tungā's relatives or his dependant minor chiefs (Rutherford 1971:111; see also Fusitu'a 1976:18-19). The Mu'a group petitioned first the King and when that did not work Queen Victoria herself to have Baker removed. Even though the Constitution had granted rights of petition, the King considered these actions seditious and brought the petitioners to trial.

Meanwhile, even though the bulk of the population, commoners, stood to gain from the Tupou-Baker reforms, the issues were more complicated than they seemed. Tupou I had unified the archipelago, but only precariously. Regional loyalties persisted, and in the eyes of many, Tupou I represented the oppressive military might of Ha'apai and Vava'u (Map 2) in the "north's" attempt to dominate Tongatapu, the "sacred south". Tāufa'āhau rose to the Tu'i Kanokupolu and eventually the royal titles as Tu'i Ha'apai and Tu'i Vava'u (Lātūkefu 1974:65-66); his helper in these campaigns was 'Ulukālala Tuapasi (Figure 4). In the wake of these accomplishments, a united and centralized north confronted a still fragmented Tongatapu (ibid.:22). Based at $\mathrm{Mu}^{\prime} \mathrm{a}$ in Tongatapu, Tungī represented not only the ancien regime, not only the insurgency of a senior line against its junior yet politically dominant branch, but Tongatapu resistance to Tāufa'āhau-instigated northern hegemony (Rutherford 1971:116-117).

When in 1885 Tupou I announced his intention to establish a Free Church of Tonga independent of the parent Conference of New South Wales (Ellem 1983:170), civil war all but broke out. A rallying point for "Old" Wesleyans was Baker's papālangi rival, the Reverend J. Egan Moulton, a staunch opponent of secession and also the person who had translated the petition the Mu'a group had sent to Queen Victoria from Tongan to English. But the political landscape these two men divided was split by other tensions and rivalries. Whereas the north quickly embraced the "King's Church", resistance developed on Tongatapu. Among the Old Wesleyan sympathizers were Tungi and the Tu'i Pelehake (Ellem 1981:132; Fusitu'a 1976:27, 46). Tupou I's own daughter, Sālote, who was married to the Tu'i Pelehake (Figure 3), refused to convert and became a Wesleyan, joining others in exile in Fiji. In Hahake spokespeople for the Wesleyans included one Tōpui, a cousin of Tungī who had been the ringleader of the Mu'a group. Other Mu'a veterans were Wesleyans as well (Rutherford 1971:130).

Matters came to a head when an effort was made on Baker's life. The plot was hatched in Mu'a. Tungì's cousin was among the would-be assassins. Rutherford thinks it probable that Tungī, his son Tuku'aho, Tu'i Pelehake, and even the Crown Prince were operating behind the scenes (ibid.:140; Rutherford 
1977:169) - presumably as a shadow government awaiting its opportunity to usurp the key positions, Baker's and the King's included. Though the attempt aborted, the perpetrators were brutally punished. To teach Tongatapu a lesson, Tupou I unleashed his northern warriors on Tongatapu, where they ransacked Wesleyan holdings and killed rapaciously (ibid.).

As a result, the British High Commissioner, Sir John Thurston, intervened and decided to deport Baker, a British subject, in part on the basis of affidavits signed by Tungī, his son, and the Tu'i Pelehake "declaring Baker to have been the sole source of Tonga's troubles" (Fusitu'a 1976:40). The new ministry Thurston established was stacked with opposition chiefs, including Tungī as chairman of Parliament and Minister of Lands, the Tu'i Pelehake as Governor of Ha'apai, and Tuku'aho, Tungī's heir, as Premier and Minister for Foreign Affairs (ibid.:42). This move would undermine the entire position of Tupou II (Fusitu'a and Rutherford 1977:174; see Campbell 1992:ch. 7).

\section{The Affinal Politics of the Twentieth Century}

When Tupou I finally died in 1893 - in his 10th or, some even say, his 11 th decade - the matter of succession was far from settled. All his heirs save one, a son's daughter's son named George Tāufa'āhau, had already died, ${ }^{24}$ and by traditional standards this descendant was not the only possible successor. Others had strong claims: Tungī, Tuku'aho, and the Tu'i Pelehake (see Figure 5), for example. Though another title was created to substitute for the Tu'i Tonga title, the Tu'i Pelehake had and still has the strongest symbolic associations with the Tu'i Tonga title. This particular Tu'i Pelehake, moreover, had married Tupou I's son's daughter and was the father of Tupou II (Ellem 1987:213; see Figure 5). Tungī was now quite old and was not eager to press his claim; but Tungī's son, Tuku'aho, son of 'Ana Seini, the great granddaughter of the Tamahā Lātūfuipeka who Tupou I had bestowed upon Tungī Halatuituia, was a viable contender. ${ }^{25}$ Siaosi Tuku'aho grew up "feeling that he had higher rank and a better claim to the throne than Tupou I's descendants" (Fusitu'a 1976:18); and he married a woman of such exceptional rank that she was fahu at the funeral of the Tu'i Pelehake in 1912 (Ellem 1981:100, n.36). So manifest were Tuku'aho's ambitions that Tupou II suspected Tuku'aho of trying to supplant him (Ellem 1981:95). Moreover, his wife, according to Ellem, was the highest ranking Old Wesleyan in the first decade of this century (Ellem 1981:111); and Tuku'aho himself was Old Wesleyan rather than Free Church in his sympathies (Fusitu'a 1976:46, 95).

To mollify Tungī Halatuituia still further, Tupou I had a "tacit" understanding with him (Fusitu'a 1976:99) that his successor would marry 'Ofaki-Vava'u, Tungī's sister's daughter's daughter and his fahu (Ellem 1981:96; see also Ellem 1987:213; Fusitu'a 1976:99; see also Seddon 1900:21). Through both her mother and her father, 'Ofa's blood rank was "exceedingly high" (Ellem 1981:96). Along 
with Tungī, she was supported by her father, Mā'atu, chief of the northern island Niuatoputapu, and 'Ulukālala Siaosi Fīnau Misini, her classificatory uncle (ibid.; see Figure 4). Since Mā'atu is a chief of the Kauhala'uta, this faction replicated the 'Ulukālala-Mulikiha'amea (Hahake Dynasty)-Tu'i Tonga faction of the end of the eighteenth century.

Misini's father's mother had been a daughter of Mā'atu (Bott 1982:151, Figure 28), and Misini carried into the twentieth century the same grudge that had set 'Ulukālala against Tupou Tu'i Kanokupolus throughout much of the nineteenth century and that had played a role in the assassination of Tuku'aho in 1799. Misini's father's father, 'Ulukālala Tuapasi (Figure 4), had opposed Tāufa'āhau's father, Tupouto'a, because Tupouto'a had failed to bestow the title of Tu'i Vava'u upon him (Figure 4). Tuapasi had eventually won that title himself; but he had failed to retain it for his line. He had combined forces with Tāufa'āhau, then Tu'i Ha'apai, with the expectation that Tāufa'āhau would name him Tu'i Vava'u once he attained the Tu'i Kanokupolu title. On his deathbed, 'Ulukālala Tuapasi is alleged to have granted Tāufa'āhau the Tu'i Vava'u title (Cummins 1980:41; Lātūkefu 1974:66, 93), presumably with the understanding that the title would revert to his heir once his heir was of age to hold it. ${ }^{26}$ But when his son later requested the title, Tāufa'āhau, now King George Tupou I, refused to bestow it upon him. Instead he appointed as governor 'Osaiasi Veikune, one of the leading chiefs of Vava'u. According to Lātūkefu, Tāufa'āhau "deliberately side-stepped Fīnau 'Ulukālala's son, Matekitonga, who was now of age, anticipating that he would try to restore himself as ruler of Vava'u if he were placed in such a position. Thus he forestalled a potential rival" (Lātūkefu 1974:94) — or at least tried to. According to Ellem, "The 'Ulukālala chiefs claimed that Tāufa'āhau ... had usurped their title of Tu'i Vava'u in 1833; and they had never ceased in their attempts to reclaim that title" (Ellem 1987:216). So it was that Matekitonga fought alongside the rebels at Pea in 1852 against Tupou I (Lātūkefu 1974:97) and was exiled for it to "Eua ("Discussions" 1:181).

Had Tupou II married 'Ofa, he would have appeased Matekitonga's son, Misini, as well as the entire Tungī line. The alternative was Lavinia, the great granddaughter of Laufilitonga, the last Tu'i Tonga (ibid.; see Figure 5). Her father's mother's mother had been Halaevalu Mata'aho, the sister Tāufa'āhau had refused to give as moheofo to Laufilitonga. Her father's father's father was 'Osaiasi Veikune, Tupou I's appointee as Tu'i Vava'u. Though Tu'i Tonga blood flowed in her veins (Marcus 1977:286), neither parent was "of truly aristocratic descent" (Fusitu'a 1976:98). ${ }^{27}$

To decide between these two women, Tupou II convened his chiefs. They hotly debated whom the King should marry. At night "the supporters of the two factions fought in the streets and burned down each other's houses", Ellem 
reports (1981:98). In the end they voted 17 to 7 in favour of 'Ofa. However, Tupou II chose to marry Lavinia. Visiting Tonga at the time of the decision, the then premier of New Zealand accounted for the King's choice in terms of his fear of being outranked by his wife. Though 'Ofa was "prepossessing" enough (Seddon 1900:21),

it happened that when negotiations were proceeding the unfortunate remark was made to the King that he would strengthen his position by marrying Ofa, because she was of better blood than himself. The pride of the monarch was aroused. "There is no one in Tonga who would not be honoured in being raised to share the throne of Tonga", he said, and conceived strong animus against the marriage. For a year the struggle went on, as to whether Ofa or the King's new choice, Lavinia, should be Queen. It ended in the King calling for the advice of his chiefs, and when they counselled his marriage with Ofa he did what it is said he had made up his mind a year before to do - viz., reject both the advice and the girl. He married Lavinia, the present Queen (ibid.:18-21; see also Ellem 1981:97). 


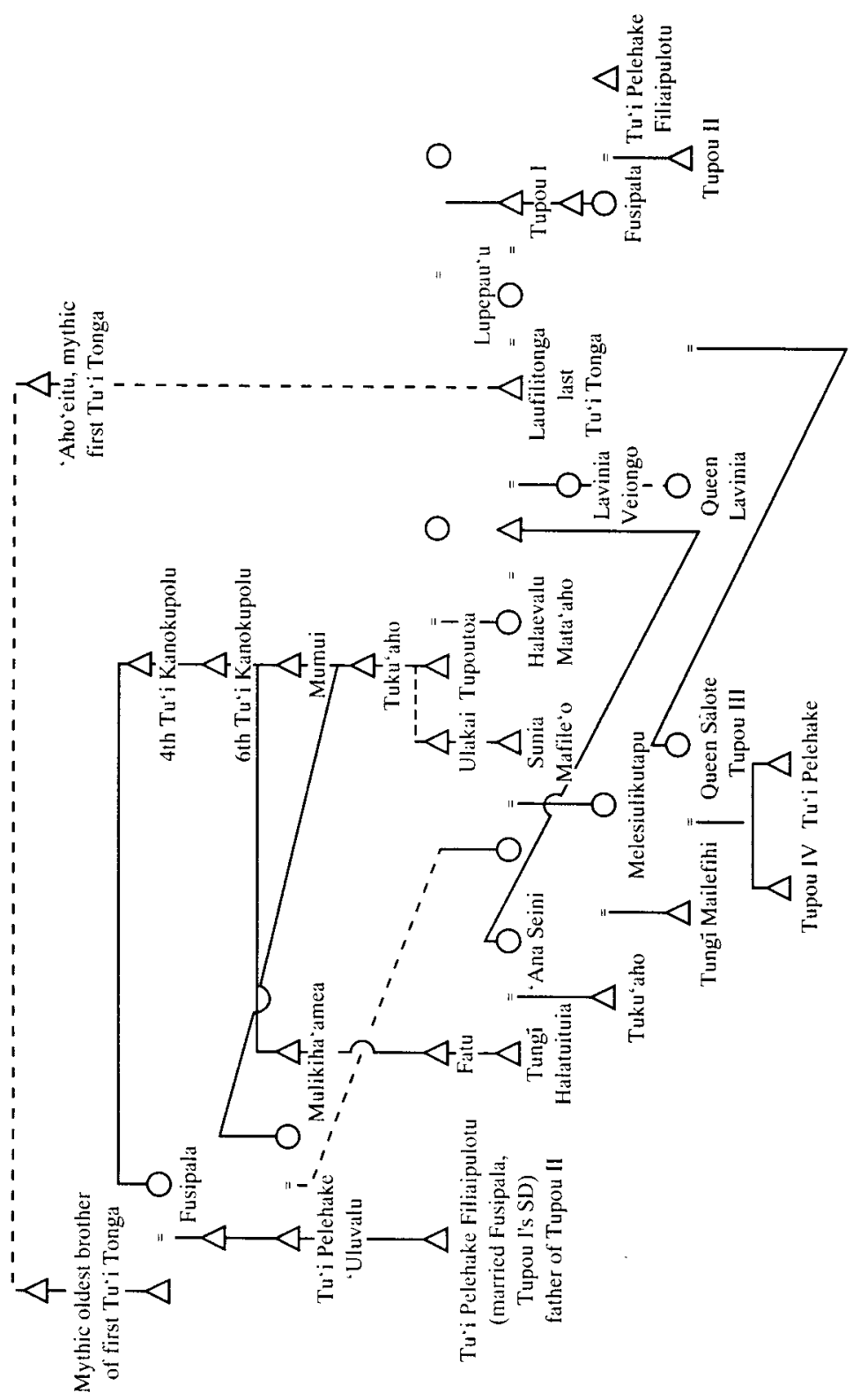

Figure 5. Genealogy of the present King (synthesized from materials in Bott (1982) and Ellem 1981)).

In the wake of the King's decision to marry Lavinia, the situation continued to be volatile.

On the day of the King's wedding, the supporters of 'Ofa carried her through the streets dressed as a bride, and they shouted the $t u$ of 
marriage processions. For nearly a year afterwards the King and his new Queen dared not leave the grounds of the Palace for fear of personal attack. Public demonstrations occurred whenever the two factions met. The funeral of 'Ofa in 1901 was marked by rioting in the streets (Ellem 1987:214).

Opposition remained vehement. The hostility toward the King and the Queen was so strong that the King placed guards around the Palace, and the couple rarely left the Palace grounds. The houses of supporters on either side were burned. "When Lavinia died in the following year, the King buried her in the royal cemetery. Her grave was marked by a costly and ostentatious monument" (ibid.).

After Lavinia died, Tupou II erratically married 'Ofa's matrilateral half-sister Takip, thereby binding to himself the opposition faction, soon to be known as the King's Party. Since Sālote was Lavinia's child, once she ascended the throne her father's supporters became her enemies; and her father's daughter by this second wife, 'Elisiva Fusipala Tauki'onetuku (known as Fusipala or Fusi [Ellem 1987:215]) became her rival.

These alignments were very much intact when it came time to choosing a husband for Sālote. The person she would marry was the son's son of Tungi Halatuituia and the son of Tuku'aho: Tungī Mailefihi, who was also related to Takipō. Tungī Mailefihi's mother was Melesiu'ilikutapu, son's son's daughter of Aleamotu'a, the eighteenth Tu'i Kanokupolu. The name mailefihi - literally "tangled myrtle" (Gifford 1929:232) or "entwined myrtle" (Ellem 1981:129; Churchward glosses fihi as "tangled; figuratively, intricate, complicated, or problematical" [1959:188]) — refers to Tungī's complex genealogy (Gifford 1929:232; see Figure 5). In his person he combined the blood of the Tupou Dynasty, the Hahake Dynasty, and the Tu'i Ha'atakalaua. The marriage was arranged, some say at Sālote's birth, to compensate Tungī Halatuituia for Tupou II's not having married 'Ofa (see Ellem 1981:131; Fusitu'a 1976:99). “On hearing the 13-gun salute ... that announced Sālote's birth on 13 March 1900, old Tungi had claimed her as the future bride of his twelve-year-old grandson Mailefihi" (Ellem 1981:101; see also ibid.:131).

The fact that Tungī Mailefihi had been Governor of Vava'u since 1912 (Ellem 1987:216) was perhaps a stumbling block to his acceptance by the 'Ulukālala Dynasty, which continued to covet that title. The King's Party had supported 'Ofa and therefore Fusipala over Sālote; and now it favoured Tungī's rival, Ha'amea, the son of 'Ulukālala Misini. 'Ulukālala Misini's supporters included those petty chiefs and matāpule who had been dispossessed of their customary rights by the Tupou-Baker reforms (Gunson 1979:48-49), and in this the issue of whether Sālote would marry Tungī or Ha'amea revived the contestations of 
the 1880s. To choose Ha'amea over Tungī would mend some fences (Ellem 1987:216). Yet this would strengthen a rival without necessarily pacifying him. And this the King did not want to do, even though he had enjoyed 'Ulukālala's support ever since having married Takipō.

When Sālote married Tungī, she strove to rejoin what had been historically rent asunder. The rift between the Hahake and Tupou dynasties had dominated much of the politics of the nineteenth century. A gesture in the direction of healing that rift had been made in 1853, when Tupou I bestowed his sister's daughter upon Tungī Halatuituia. At the time this had "placated" Tungī (Ellem 1981:68), though it did not in the long run quell his opposition to the King, as I have shown. Like his father, Tuku'aho, Tungī Mailefihi had strong claims to the throne. (Ellem reckons that he was third in line at the time of his marriage [ibid.].) In choosing Lavinia over 'Ofa, Tupou II had chosen against uniting the Hahake and the Tupou dynasties, perhaps out of fear of empowering a Hahake-based opposition. The marriage of Sālote and Tungī Mailefihi was designed to effect this reconciliation. Since Tungi represented the Tu'i Ha'atakalaua while Sālote's mother carried the Tu'i Tonga blood (Figure 5), the fractures of the eighteenth century that had deepened in the nineteenth century would finally be healed (see Ellem 1981:59). In the 1880s, the north-south rift had been exacerbated by the controversy over Tupou I's establishment of an independent Wesleyan Church. As of 1921, Ha'apai and Vava'u were overwhelmingly Free Wesleyan Church while Tongatapu contained most of the Old Wesleyans (Ellem 1983:166, n.10). At the time of their marriage, Sālote "was the temporal head of one church [the Free Church], and [Tungī] the highest ranking chief in another [the Wesleyan Church]" (Ellem 1983:166). In her speech to Parliament in 1925, the year following reunion, she said: "let us give our best to unite Tonga into one happy and contented people. It is my earnest wish ..." (Ellem 1987:182).

Yet unification remained elusive. An opposition crystallized around issues of church and (state) marriage and included those who had supported 'Ofa, Fusipala, and Sālote's marriage to Ha'amea. 'Ulukālala Misini was its leader (Figure 4). As in the Mu'a Parliament affair, the antiroyal party included minor chiefs and matāpule whose customary land rights were denied by the Tupou-Baker reforms (Ellem 1983; 1987:217). Sālote and Tungī's attempt to merge the two churches in 1924 was opposed by Misini, who "demonstrated his continued alliance with the dispossessed chiefs by heading the dissident Free Church ..." (Gunson 1979:49). A way of dispensing with this opposition was to dispense with the title. Accordingly, the 'Ulukālala title was vacant from 1960 to 1989 , when the King appointed his second-born son to the title. 


\section{The King's Body}

While scholars such as Bott and Marcus have insisted upon the importance of conceptually distinguishing power from authority (Bott 1981, 1982; Marcus 1980), this distinction is effectively blurred in Phyllis Herda's “Gender, rank and power in Tonga".

Much has been made in the literature of the lack of pule (authority) of the sister and the father's sister, it being claimed that, at most, she influenced her brothers and their children in their rule, but did not effectively control or influence affairs [here she cites Kaeppler 1971, Rogers 1977, and Bott 1981]. This appears, in many respects, to be an anachronistic understanding of the extent of 'influence' in traditional Tonga. Before the advent of fixed hereditary title succession which was initiated by the Constitution of 1875, title succession was fiercely competitive; in such a situation, the power to influence the choice of successor would be great (Herda 1987:197).

She goes on to elide the distinction between specifically feminine powers, the powers a woman exercises over her brother and his children, on the one hand, and the jurisdiction a chiefly titleholder exercises over people and land, arguing that "some Tongan women held politically active titles distinct from those which emphasized their sacred sister role" (ibid.:198-199) and concluding therefore that "chiefly women were not, categorically, denied titles or legitimate access to political power" (ibid.:198). Herda's test case is Tupoumoheofo.

Tupoumoheofo's actions have been explained away by foreign observers as 'subversive', 'tyrannical' and 'odious in the extreme' and Tupoumoheofo herself described as an 'extremely ambitious, scheming woman', a 'meddling wife' and 'nothing at all to the credit of her sex'. However, it will be argued that Tupoumoheofo's actions were in accordance with her position and, more importantly, her rank in Tongan society and that her negative portrayal represents the European misunderstanding of female roles in pre-Christian Tonga, particularly as they related to the political sphere, rather than denoting unfeminine Tongan behaviour (ibid.:195; emphasis added).

I would agree with Herda that the father's sister's power to curse and a woman's ability to choose her brother's children's marriage partners are substantial powers (ibid.:197), and I would also concur that some women did indeed aggrandize significant power in the political arena itself. But I would have to insist upon the transgressive nature of Tupoumoheofo's deeds. According to the model if not the reality, in the pre-Constitutional era titleholders were not women. (This does not detract, of course, from Herda's point that Western observers judged events ethnocentrically.) Tupoumoheofo's actions were entirely 
transgressive - not only in terms of what she did but in terms of how she did it. Installation to the Tu'i Kanokupolu title occurs within the context of a kava ceremony attended by subordinate chiefs, who thereby display their fealty and essentially elect the titleholder on the basis of attributes such as seniority, blood rank, suitability (Biersack 1991a; Bott 1972; Valeri 1989). Though Tupoumoheofo placed her back against the koka tree that all Tu'i Kanokupolus placed their back against when they were installed, she could not thereby appoint herself. Herda knows this, for she writes: "No individual could simply appropriate the title, he had to be called to it" (Herda 1987:100). If indeed Tupoumoheofo did install her son as Tu'i Tonga while Tu'i Tonga Paulaho was still alive (see n.17), this act also was transgressive ("Discussions" 1:44; Bott 1982:41-42). Similarly, if her intention was to reunify the Kauhala'uta and the Kauhalalalo, the "sacred" and "working" titles, this too constituted a major violation (see Ellem 1981:61; see n.18). In fact, it could be argued that the transgressions as such were appropriate to Tupoumoheofo's position, for as moheofo she could operate across and not just within categorical boundaries (Biersack 1982 [1974]).

When King George Tāufa'āhau Tupou IV, the present king (Figure 1), ascended the throne, he was hailed as the long-awaited embodiment of the blood of all three ancient lines. Through his mother, daughter of Lavinia Veiongo, he traced descent from Laufilitonga, the last Tu'i Tonga, the Tamahā Lātūfuipeka, and the half-sister of Tāufa'āhau; through his father he traced descent from the last Tu'i Ha'atakalaua and the Tu'i Pelehake, in whom the Tu'i Tonga's kava privileges were vested and who symbolized the Tu'i Tonga and the Kauhala'uta side (Ko e Kalonika Tonga, June 30, 1967; see Figure 5). The title he held prior to his accession and still holds is his father's title, Tungī. His younger brother was made the Tu'i Pelehake. Now at the "summit" (tumutumu) of a transformed Tongan society, the present King, descendant of a nineteenth-century usurper, is the living emblem of a unity that was historically achieved through a weaving together of bloodlines.

The King's body is emblematic of the fact that in Tonga centralization is achieved historically and horizontally, through marriage, rather than structurally and vertically, through descent. This contravenes the divisions rehearsed herein: blood and garland, marriage and descent, a domain of feminine empowerment and a domain of masculine empowerment. If the present King governs as the embodiment of the blood of the three branches (Figure 1), then the distinction between these domains is effectively collapsed, and transgression assumes the status of an "organizing principle". My account is far more replete with examples of male transgressions than it is with examples of female transgressions. For example, whereas the father's sister theoretically chooses her brother's children's spouses, it is clear enough from this history that men exploit marriage in pursuit 
of their own political ambitions. As usurper, Tāufa'āhau's career was largely transgressive.

Normative sociology places structure and event in causal relationship. As a result, it can explain conformity and reproduction but not transgression and transformation. Is there a sociology consistent with the Tongan historical record?

The Tongan title system is part of an encompassing totality that turns on an axis of blood and garland. Formal analysis is thus centred upon this axis. A rule of matrilateral cross-cousin marriage would integrate and align blood and garland statuses, allowing the system as such to be operationalized. However, as Kaeppler has emphatically stated, élite marriage is a matter of choice. Matrilateral cross-cousin marriage "was not prescribed, proscribed, or preferred, but was occasionally practiced among the highest chiefs to prevent social repercussions that might result if a Tu'i were outranked by a collateral line" (Kaeppler 1971:192-193, n.25). It is therefore impossible to construe élite marriage as the mere "execution" of a rule (Bourdieu 1977:24) or as an "instantiation" of structure. Rather, Tongan élite marriage must be construed as a political tool for positioning actors across status fields. Élite marriage is always strategic - a matter of consolidating or upgrading rank and of mobilizing resources and labour in the pursuit of chosen ends. As Bott observed more than twenty years ago: "In the traditional system the object of the social and political game was to use one's standing in one system [kāinga] to increase one's standing in the other's [ha'a], marriage being one of the main devices for doing so. The process took several generations"' (Bott 1972:219).

Whether a line rises or falls, élite marriage is therefore always a practice. But it is a practice in which the blood/garland system is fully implicated, as the ground of the practice's pragmatics and politics. Rather than suppressing time, blood/garland creates a number of possible futures. These futures are conservative or radical, depending upon the goals of the players and the strategies they employ. The moheofo institution, for example, resolves the uncertainties of the blood-garland relationship conservatively, by way of reinforcing existing status asymmetries in the title system. Thus, until a certain point, the Tu'i Ha'atakalaua, directly subordinate to the Tu'i Tonga, supplied the Tu'i Tonga with his principal wife or moheofo (Figure 1). Yet juniors could also withhold a sister from a senior or appropriate the senior's wife, thus altering the status quo. As the Tu'i Tonga title began to decline in effective power, the Tu'i Kanokupolu began sending wives to the Tu'i Tonga, just as other chiefs began sending women to the Tu'i Kanokupolu (Biersack 1982 [1974]; Bott 1981, 1982; Fusitu’a 1976:10).

Sahlins has defined the event as "a relation between a happening and a structure (or structures)" (1985:xiv). For Tonga the word happening is problematic, since it implies happenstance rather than the motivated political entrepreneurship that is so much in evidence in the Tongan historical record. I 
would reformulate Sahlins' definition of an event as follows: an event is a relation between a practice - motivated and intentional - and a system - in this case, the blood/garland system. Regardless of whether conjugal practices result in reproduction or transformation, since the system is always fully implicated in the practice as the ground of its pragmatics and its politics, practice remains "internal" but without being determined by the system.

If the relationship between practice and system is thus redefined, formal analysis acquires new powers and also new limitations. Since there is no direct, causal relationship between system and practice, formal analysis alone cannot explain behaviour. However, since the system is the ground of the pragmatics and the politics of practice, formal analysis becomes a preliminary step in understanding the field of historical action and historical action itself. Actors act out of their interests as their position stipulates these interests and by way of exploiting the possibilities for empowerment the system opens up. Historical analysis thus centres on the relation between the system and (rather than the happening) the practice - that is, on the event, construed as a relation between the two (cf. Sahlins 1985:vii). The resulting theory of Tongan history is at once event-centred (Biersack 1991b) and highly political. It understands actual events in terms of an actor's possible moves and their political consequences, and it is as equipped to explain moments of transformation as it is to explain moments of reproduction. This is precisely the strength, it seems to me, of Goldman's theory of status rivalry. As he argued in Ancient Polynesian Society, "structure ... allows for shifts in power relationships, offering several leverage points for such shifts" (Goldman 1970:304-305). Structure energizes (to use Goldman's figure of speech) or motivates a field of political actors and informs their initiatives. What becomes characteristic, therefore, is a range of practices, a historical culture (cf. Sahlins 1985).

Attention thus shifts from structure to structuring (Giddens 1979) in the very strongest sense of the word: to activities of making and remaking. Tongans themselves speak of such activities in terms of $\mathrm{fa}^{\prime} u$. As a verb the word means "to bring into existence; to make, construct, put together; to build ...; to found, institute; to formulate, draw up, making, bring in (a law, etc.) ..." (Churchward 1959:147); and as a noun the word means "bringing into existence, constructing, etc.; plan, measure, or institution; thing formed or constructed" (ibid.). These words accent the activity of construction rather than its product; they call attention to a certain kind of agency. Integrating blood and garland in such a way as to uphold the status quo, the moheofo institution was one such fa'u: not a structure of alliance so much as a structuring through alliance. Whether the action maintains the status quo or encourages change, in either case the hierarchy of titles is generated through marriage as a $f a^{\prime} u$ or artefact of historical practices. The Constitution of 1875 is itself the much celebrated fa' $u$ of King George Tupou I. It retained some titles, dropped others, and strategically added new ones - 
the Tungī title, for example — erecting a new order of noppele titles upon the ancient foundations (Biersack 1990a).

The rank of the body is a personal rank, the rank of the historical individual. The present King's body represents the totality in terms of a historical genealogy: the many acts of structuring and restructuring that the last two hundred years have witnessed. It is a $f a^{\prime} u$. In and of itself it signifies the historicality of political life (cf. Valeri 1985, 1990b) and the historicity of the Tongan ramage.

\section{References}

Biersack, Aletta

1982 Tongan exchange structures: beyond descent and alliance. Journal of the

[1974] Polynesian Society 91(2):181-212. (Revision of "Matrilaterality in patrilineal systems: the Tongan case", Curl Bequest Prize Essay, R.A.I., 1974.)

1990a Under the toa tree: the genealogy of the Tongan chiefs. In Jukka Siikala (ed.) Culture and history in the Pacific. Helsinki: Finnish Anthropological Society.

1990b Blood and garland: duality in Tongan history. In P. Herda, J. Terrell and N. Gunson (eds) Tongan culture and history. Canberra: Target Oceania and the Department of Pacific and Southeast Asian History, Research School of Pacific Studies, The Australian National University.

1991a Kava'onau and the Tongan chiefs. Journal of the Polynesian Society 100(3):231-268.

1991b History and theory in anthropology. In Aletta Biersack (ed.) Clio in Oceania: toward a historical anthropology. Washington, DC: Smithsonian Institution Press.

Bott, Elizabeth

1958/59 Discussions with Queen Sālote. 2 vols. BSP 25.

1972 Psychoanalysis and ceremony. In J.S. La Fontaine (ed.) The interpretation of ritual: essays in honour of A.I. Richards, pp.205-237. London: Tavistock Publications.

1981 Power and rank in the kingdom of Tonga. Journal of the Polynesian Society 90(1):7-81.

Bott, Elizabeth, with the assistance of Tavi

1982 Tongan society at the time of Captain Cook's visits: discussions with Her Majesty Queen Sālote. Memoir No. 44. Wellington: The Polynesian Society. 
Bott Spillius Papers (BSP)

Manuscripts and Archives Collection, New Zealand and Pacific Collection, The Library, University of Auckland, New Zealand.

Bourdieu, Pierre

1977 Outline of a theory of practice. Cambridge: Cambridge University Press.

Campbell, Ian

1982 The Tu'i Ha'a Takalaua and the ancient constitution of Tonga. Journal of Pacific History 17:178-194.

1989 The demise of the Tu'i Kanokupolu. Journal of Pacific History 24(2): 150163.

1992 Island kingdom: Tonga ancient and modern. Christchurch: Canterbury University Press.

Churchward, C. Maxwell

1959 Tongan dictionary. Nuku'alofa: Tonga Government Printing Press.

Collocott, Rev. E.E.V.

Miscellaneous Papers 1922-62. MS 1058:1, p.19. Alexander Turnbull Library.

Collocott, Rev. E.E.V. and Sione Havea

1922 Proverbial sayings of the Tongans. Occasional Paper No. 8. Honolulu: Bernice P. Bishop Museum.

Cummins, H.G.

1980 Missionary chieftain. PhD thesis, The Australian National University, Canberra.

Dumont D'Urville, J.M.

1989 Voyage pittoresque autor du monde. Papeete: Editions Haere Po.

Ellem, Elizabeth Wood

1981 Queen Sālote Tupou III and Tungī Mailefihi: A Study of Leadership in Twentieth Century Tonga (1918-1949). PhD thesis, Department of History, University of Melbourne.

1983 Sālote of Tonga and the problem of national unity. Journal of Pacific History 18(3):163-182.

1987 Queen Sālote Tupou of Tonga as Tu'i Fefine. Journal of Pacific History 22(4):209-277.

Fanua, Tupou Posesi 
n.d. Wistful thoughts of the past and the future, with explanatory notes (fakamatala) by Tupou Posesi Fanua and Wendy Pond. (Typescript in the possession of the author.)

Fox, James J.

1988 Origin, descent and precedence in the study of Austronesian societies. Public Lecture in connection with De Wisselleerstoel Indonesische Studien, given on 17th March 1988. Published, Leiden University.

1994 Reflections on "hierarchy" and "precedence". In M. Jolly and M. Mosko (eds) Special Issue of History and Anthropology. Transformations of hierarchy: structure, history and horizon in the Austronesian world, 7(1-4): 87108. Chur and Reading: Harwood Academic Publishers.

1995 Austronesian societies and their transformations. In P. Bellwood, James J. Fox and D. Tryon (eds) The Austronesians: historical and comparative perspectives, pp.214-228. Canberra: Department of Anthropology, Research School of Pacific and Asian Studies, The Australian National University.

Fusitu'a, Eseta

1976 King George Tupou II and the government of Tonga. MA thesis, The Australian National University, Canberra.

Fusitu'a, Eseta and Noel Rutherford

1977 George Tupou II and the British Protectorate. In N. Rutherford (ed.) Friendly Islands: a history. Melbourne: Oxford University Press.

Giddens, Anthony

1979 Central problems in social theory. Berkeley: University of California Press.

Gifford, Edward Winslow

1929 Tongan society. Bernice P. Bishop Museum Bulletin 61. The Museum, Honolulu.

Goldman, Irving

1970 Ancient Polynesian society. Chicago: University of Chicago Press.

Gunson, Niel

1977 The coming of foreigners. In N. Rutherford (ed.) Friendly Islands: a history. Melbourne: Oxford University Press.

1979 The Hau concept of leadership in Western Polynesia. Journal of Pacific History 14:28-49. 
1987 Sacred women chiefs and female "headmen" in Polynesian history. In C. Ralston and N. Thomas (eds) Sanctity and power: gender in Polynesian history. Special issue of Journal of Pacific History 22(3-4): 139-171.

Herda, Phyllis S.

1987 Gender, rank and power in 18th century Tonga: the case of Tupoumoheofo. Journal of Pacific History 22(4):195-208.

1988 The transformation of the traditional Tongan polity: a genealogical consideration of Tonga's past. PhD thesis, Department of Pacific and Southeast Asian History, Research School of Pacific Studies, The Australian National University, Canberra.

James, Kerry

1991 The female presence in heavenly places: myth and sovereignty in Tonga. Oceania 61:287-308.

1992 Tongan rank revisited: religious hierarchy, social stratification, and gender in the ancient Tongan polity. Social Analysis 31:79-102.

Kaeppler, A.L.

1971 Rank in Tonga. Ethnology 10:174-193.

Lātūkefu, Sione

1974 Church and state in Tonga. Canberra: Australian National University Press.

1975 The Tongan Constitution: a brief history to celebrate its centenary. Nuku'alofa: Tonga Traditions Committee Publications.

1977 The Wesleyan mission. In N. Rutherford (ed.) Friendly Islands: a history. Melbourne: Oxford University Press.

1980 The definition of authentic Oceanic cultures with particular reference to Tongan culture. Pacific Studies 4:60-81.

Linnekin, Jocelyn

1990 Sacred queens and women of consequence. Ann Arbor: The University of Michigan Press.

Māhina, ‘Okusitino

1986 Religion, politics and the Tu'i Tonga empire. MA thesis, University of Auckland.

Marcus, George

1977 Succession disputes and the position of the nobility in modern Tonga. Oceania 47(3, 4):220-241, 284-299. 
1980 The nobility and the chiefly traditions in the modern kingdom of Tonga. Memoir No. 42. Wellington: The Polynesian Society.

Martin, John [William Mariner]

1981 Tonga islands: William Mariner's account, 4th ed. [1st published London, 1817.] Tonga: Vava'u Press.

Rogers, Garth

1977 "The father's sister is black": a consideration of female rank and power in Tonga. Journal of the Polynesian Society 86(2):157-182.

Rutherford, Noel

1971 Shirley Baker and the King of Tonga. Melbourne: Oxford University Press.

1977 George Tupou I and Shirley Baker. In N. Rutherford (ed.) Friendly Islands: a history. Melbourne: Oxford University Press.

Sahlins, Marshall

1958 Social stratification in Polynesia. Seattle: University of Washington Press.

1976 Culture and practical reason. Chicago: Chicago University Press.

1981 Historical metaphors and mythical realities: structure in the early history of the Sandwich Islands kingdom. Association of Social Anthropologists of Oceania Special Publication No. 1. Ann Arbor: The University of Michigan Press.

1985 Islands of history. Chicago: University of Chicago Press.

Seddon, The Right Hon. R.J. (Premier of New Zealand)

1900 Visit to Tonga, Fiji, Savage, and the Cook Islands, May 1900. Wellington: Government Printer.

Spillius, James

n.d. Unnamed PhD thesis concerning Tonga, Samoa, and Tikopia. BSP, Box 4.

Thomas, John

1879 History of the Friendly Islands. CY Reel 446; ML A 1961, frames 92-323.

n.d. Journals.

Thomson, Basil

1894 The diversions of a Prime Minister: life in the Friendly Islands, 1887-1891. Edinburgh: Blackwood.

Valeri, Valerio

1972 Le fonctionnement du systéme des rangs á Hawaii. L'Homme 12:29-66. 
1985 The conqueror becomes king: a political analysis of the Hawaiian legend of 'Umi. In Antony Hooper and Judith Huntsman (eds) Transformations of Polynesian culture. Memoir No. 45. Auckland: The Polynesian Society.

1989 Death in heaven: myths and rites of kinship in Tongan kingship. History and Anthropology 4:209-247.

1990a Diarchy and history in Hawaii and Tonga. In Jukka Siikala (ed.) Culture and history in the Pacific. Helsinki: Finland Anthropological Society.

1990b Constitutive history: genealogy and narrative in the legitimation of Hawaiian kingship. In Emiko Ohnuki-Tierney (ed.) Culture through time: anthropological approaches, pp. 154-192. Stanford: Stanford University Press.

1994 On female presences and absences in heavenly places. Oceania 65:75-93.

Wood, A.H.

1932 A history and geography of Tonga. Nuku'alofa: Government Printer.

\section{Notes}

1 This paper was initially drafted while I held a grant-in-aid from the American Philosophical Society and was a Visiting Fellow with the Comparative Austronesian Project, Research School of Pacific and Asian Studies, The Australian National University. It was revised for publication in light of further research while I held a NEH Travel to Collections grant. Dr James Fox was the convener of the project. It is based in part on research I completed under grants-in-aid from the Wenner-Gren Foundation for Anthropological Research and the American Council of Learned Societies and a summer research award from the University of Oregon, all in 1986. I thank also Dr Niel Gunson and the Department of Pacific and Southeast Asian History, Research School of Pacific Studies, for a visiting fellowship in that department in January 1987. Others have also been encouraging and helpful: Tupou Posesi Fanua, Futa Helu, Adrienne Kaeppler, Sione Lātūkefu, “Okusitino Māhina, George Marcus, the late Garth Rogers, Tavi, 'Ofa Tulimaiau, Takapu, Pohiva Vaimo'unga, Valerio Valeri, and the late honourable Ve'ehala. I am indebted to Drs Fox and Sather and especially to Drs Ian Campbell and Niel Gunson for their thoughtful critiques of a prior version. I also wish to thank Richard Brown, Suzanna Layton and Clive Moore, all of The University of Queensland, for assistance in locating a key text in the eleventh hour of preparing this article for publication. Any errors of fact or interpretation remain my own.

2 I use the word usurper in a rather loose sense. I do not mean to imply that Tâufa'āhau appropriated a title that another person by rights should have succeeded to. Tāufa'āhau rightly claimed the Tu'i Kanokupolu title; and since the royal title, King, was of his invention, it is impossible to argue that he illegitimately held that title. However, the King title in effect displaced the Tu'i Tonga title and it placed Tāufa'āhau, as King George Tupou I, at the top of the title system. Since Tāufa'āhau had no birth right to the "summit" (tumutumu) of Tongan society, in the broad sense of the word he was a usurper.

3 The literature on ancient Hawai'i similarly emphasizes the political uses of marriage. Valeri's "Le fonctionnement du systéme des rangs á Hawaii" was the first to discuss this matter. The topic has been pursued by Sahlins (1981 and 1985), Valeri (1985, 1991) and Linnekin (1990).

4 I hope I do not misrepresent her argument in saying that Kerry James envisions the source of status — "rank", in her terminology — as ultimately feminine (James 1992). While the Tongan polity (traditionally and yet today) is clearly religious, as James claims, to emphasize blood- and female-derived status over title, with its masculine associations, is to miss the crucial distinction between blood and garland that Tongans themselves seem to draw and which informs my argument. After all, the first Tu'i Tonga was 'Aho'eitu, a male; he was killed by his heavenly older brothers; to reward him 'Aho'eitu's father, 'Eitumatupu'a, sent him back home on earth and installed him as the first Tu'i Tonga; and to punish the brothers, the same father sent them with 'Aho'eitu to serve as his assistants and subordinates (Biersack 1991a; Bott 1972; Māhina 1986; Valeri 1989). The charter of the political system as a religious 
system could be neither more patriarchal nor more focused on fraternal rivalry (see also the exchange between James (1991) and Valeri (1994)).

5 BSP refers to the Bott Spillius Papers in the New Zealand and Pacific Collection of The Library, University of Auckland. The tripartite number scheme refers to box number, file number, and page number, respectively. These papers are a compilation of the work of three authors: primarily Elizabeth Bott (then Elizabeth Spillius), James Spillius and Queen Sālote Tupou III. During the period 1958-1960, when Bott was in the employ of the Tonga Traditions Committee, Bott interviewed Queen Sālote as their principal informant on Tongan history and culture; and Spillius did so as well, although to a lesser extent. In the two-volume compilation of interviews with Queen Sālote called "Discussions with Queen Sālote", Bott records the answers Queen Sālote principally, but also occasionally Ve'ehala, gave to her questions, as well as the questions themselves. In citing documents from this collection, where no author is designated, the author of the cited document is Bott.

6 While Bott here associates pule with the juridical power of the chiefs, the power they exercised over land and people, pule or "authority" may refer to the authority of the father's sister as well (Lātūkefu, pers.comm.). Similarly, whereas I have distinguished the $h a^{\prime} a$ from the kāinga system, the idiom of the chief-villager relationship was an idiom of kinship (Lātūkefu, pers.comm.; 1975:9, 1980:65-66), an idiom that reflects the moral character of governance in Tonga (Biersack 1990b, 1991a; Valeri 1989, 1990a).

7 Bott notes that Lātūnipulu is sometimes described as a male Tamahā, but dismisses the possibility. "What seems most probable is that the actual title of Tamahā was bestowed only on ... three women ..., but that there was also a less precise usage by which all the people who stood in the right relationship were called Tamahā even if the actual title had not been specifically granted to them. The evidence of Cook strongly suggests that this was so. In any case, it is clear from Cook's account that Lātūnipulu and his sisters, as well as their mother, were of higher rank than the Tu'i Tonga" (Bott 1982:35).

8 A woman who was given as a secondary wife by her kinswoman, the primary wife of her husband, was called fokonofo (Bott 1982:77).

9 However, according to Bott (1982:74, Figure 9), Makahokovalu died before succeeding to either.

10 Ellem expresses serious reservations about the story of Tāufa'āhau withholding Halaevalu Mata'aho from Laufilitonga. She writes that this legend "presupposes that the heir of the Tu'i Tonga could only be the son of the moheofo, and that the Tupou Dynasty could provide the moheofo, although Tupouto'a [Tāufa'āhau's father] was dead" (Ellem 1981:66) and Tāufa'āhau was not yet Tu'i Kanokupolu (ibid.). Regardless of whether it is true, the story reveals a recognized strategy for besting a rival. According to Gunson, Tāufa'āhau's refusal to send his sister to the Tu'i Tonga was the official cause of the famed Battle of Velata (Gunson 1979:47), where Tāufa'āhau trounced Laufilitonga. It was only after Tāufa'āhau defeated the Tu'i Tonga at Velata and Tāufa'āhau was recognized as a "conqueror" or hau that Laufilitonga was installed as Tu'i Tonga (in 1827) and Halaevalu Mata'aho was transferred as his moheofo (ibid.).

11 For example, the 'Ahome'e title of the Ha'a Ngata Motu'a appears to have been incorporated within the Ha'a Ngata through marriage, since the first Tu'i Kanokupolu married the daughter of 'Ahome'e, who was then a chief in the Hihifo district of Tongatapu appointed, presumably, by some other chief, the title having been transferred from one $h a^{\prime} a$ to another with the Tu'i Kanokupolu's acquisition of the right to appoint it (see Bott 1982:13).

12 Writing in 1929, Gifford stated that "the late chief Tuita was spoken of as mua 'eiki, because his father as a navigator (toutai) was matapule and his mother, the daughter of the Tamahā Amelia, was of chiefly rank" (1929:109). Queen Sālote reinforced the perception, speaking of the Tuita title as an 'eiki matāpule in 1958/59 ("Discussions" 2:296).

13 Though the Tu'i Pelehake was given the special kava tapus of the Tu'i Tonga, he was not the titular representative of that title. That honour fell to Kalaniuvalu.

${ }^{14} M u^{\prime} a$ implies both spatial and temporal precedence; it means "front, space or place in front or further forward" and also "earlier time or period" (Churchward 1959:372). It opposes mui, "to be or go behind" and "back, rear, hind" and also "young, immature" and "later, second" (ibid.:370).

15 Ellem merely lists Mulikiha'amea as Tu'i Kanokupolu (1981:451, Figure 2), and Bott places a question mark over the possibility of Mulikiha'amea's holding the Tu'i Ha'atakalaua title (1982:13, Figure 2). However, in a piece labelled "Tonga a Brief History" and written in Bott's hand as an appendix of a chapter to the dissertation her then husband James Spillius was writing on Tonga, Samoa, and Tikopia, Bott writes that "Mulikihaamea was the last Tu'i Ha'a Takalaua" (BSP 4/5/36). In yet another piece, "Re Feudalism", Bott speaks of Maealiuaki as the "last certain Tu'i Ha'atakalaua" (BSP 22/3), as do Fusitu'a 
(1976:17), Gifford (1929:86), Gunson (1977:99, 1979:40-41 and 1987:18), and Lātūkefu (1977:115). However, Gifford also refers to Mulikiha'amea as "the last Tu'i Ha'a Takalaua" (1929:84); and Bott equivocates in her publications: "According to Tungī, husband of Queen Sālote, Maealiuaki was the last Tu'i Ha'a Takalaua, though some sources say that his son Mulikiha'amea became Tu'i Ha'a Takalaua too" (Bott 1982:64). Queen Sālote herself equivocated ("Discussions" 1:60). It has also been proposed that Mumui was at one point named Tu'i Ha'atakalaua, though Campbell does not agree (Campbell 1982:188). Herda is noncommittal on the question of whether Mulikiha'amea was ever Tu'i Ha'atakalaua (1987:203).

16 Campbell (1989) does not acknowledge that Tu'i Halafatai, Tupoumoheofo's full brother, ever became Tu'i Kanokupolu; and he does not list his son as having succeeded either. According to Gifford (1929:88) and Wood (1932:26), Tu'i Halafatai actually was Tu'i Kanokupolu for a time but gave up the title and went to Fiji in 1782 (see also "Discussions" 1:44).

17 Interpretations of Tupoumoheofo's apparent attempt to install her son as Tu'i Tonga while his father was still alive also vary. Herda claims that it was Paulaho himself who wished to assure the accession of his son because his own position was precarious, and Gunson now agrees that the initiative was Paulaho's, not Tupoumoheofo's (pers. comm.). Meanwhile, Campbell claims that Fuanunuiava was fully appointed Tu'i Tonga in 1795 by Mumui himself, in the interest of stabilizing the situation (Campbell 1982:186; see also Campbell 1992:39-40).

Much remains unclear about this episode. Fuanunuiava was not the first-born son and he appears not to have had his father's moheofo as his mother's (Herda 1987:202-203, ibid.:n.31; 1988:97). Herda bases this conclusion on a genealogy Niel Gunson collected in Vava'u (Herda 1988:9, n.80). Gunson tells us much more about this genealogy in his own paper "Sacred Women Chiefs and Female 'Headmen' in Polynesian History". It is "a genealogy of the descendants of [Tu'i Tonga] 'Uluakimata recorded or copied by a member of the family of the Hon. Ma'afu Tupou, governor of Vava'u" (Gunson 1987:142, n.16). He vouches for the accuracy of this genealogy in the following way: "The accuracy of this elaborate record has been confirmed by a number of tests involving cross referencing with other genealogies and with obscure documentary references for the period before 1822" (ibid.); but, as he also tells us, this is the only genealogy in which the name Inumofalefā, a secondary wife, rather than Tupoumoheofo is given as the mother of Fuanunuiava (ibid.:162, n.86). Since this "well-authenticated genealogy" (ibid.) agrees with no other known genealogy on this point, and it appears to disagree with all known oral tradition, perhaps its evidence, at least in this regard, is to be set aside. If, as Gunson suggests, Fuanunuiava was adopted and raised as Tupoumoheofo's son, thus accounting for the ubiquitous impression that Tupoumoheofo was his mother (ibid.), whether Tupoumoheofo was Fuanunuiava's biological mother becomes immaterial anyway. What Herda leaves unexplained, assuming that Tupoumoheofo was not the mother of Fuanunuiava, however, is why Tupoumoheofo's own son was not acceptable. If Paulaho had legitimacy problems, surely he would have wanted to avoid compounding them through an irregular succession in the next generation. Also, if, as Herda tells us, there was "no specific installation ceremony for the Tu'i Tonga" (Herda 1988:98), it is not clear what Paulaho accomplished in subjecting himself to the humiliation of having his own son breach the tapus on eating in the presence of the father.

Herda also claims that the title, presumably the Tu'i Tonga title, passed to Ma'ulupekotofa's full sister, Nanasipau'u, upon his death, Fuanunuiava acquiring the title only after his mehekitanga died (Herda 1987:203). Yet Bott lists Nanasipau'u as the Tu'i Tonga Fefine and not as the Tu'i Tonga (Bott 1982:33). Indeed, no other scholar has suggested that there was ever a female Tu'i Tonga, and, as I have explained, the Tu'i Tonga Fefine was not a title in the ha'a system.

For her part, Bott expresses confusion about the irregularity of Paulaho's succession, for his higher ranking brother, Ma'ulupekotofa, whose mother was a Tamahā and who appears to have been older, does not precede Paulaho but assumes the title only upon Paulaho's death (Bott 1982:99-100).

18 One casualty of Tupoumoheofo's machinations was her husband, the Tu'i Tonga Paulaho. Accounts of Pau's demise vary. Some say that he was deposed because of his wife's outlandish behaviour (Gifford 1929:50; Wood 1932:26). Queen Sālote believed that Pau had voluntarily retired from the Tu'i Tongaship because Tupoumoheofo had installed her son, Fuanunuiava, while his father was still alive and this made a mockery of the title ("Discussions" 1:60; cf. Herda's interpretation 1987:201-202). Others envision Tupoumoheofo as agitating against her husband. Herda claims that she conspired with Mumui and Vuna, the Tu'i Vava'u and her son-in-law, against Paulaho (Herda 1987:206; Herda 1988:99; see also Ellem 1981:60, n.22); and Gunson also supports a conspiracy theory (1979:29, 40). Others attribute the decline of the Tu'i Tonga to Paulaho's and his son's penchant for meddling in secular affairs (Spillius n.d.: ch.5, BSP 4/3/46). Theoretically the Tu'i Tonga was a ritual rather than a political leader, the "most 
sacred chief" and not the "working chief" (Biersack 1990a; Valeri 1989, 1990a); and this meddling was a clear breach of the division of labour between the sacred and the working chiefs.

${ }^{19} \mathrm{He}$ also (at least in some accounts) made common cause with Tupoumoheofo and Mumui, Tuku'aho's father, in overthrowing Tupoumoheofo's husband, Paulaho (Gunson 1979:40; Herda 1987:206).

20 These included Tuku'aho's own patrilateral half-brother Tangata-'i-Lakepa (Bott 1982:146), who apparently backed Mulikiha'amea as the next Tu'i Kanokupolu (Herda 1988:114).

21 The 'Ulukālalas nonetheless undercut any residual power or status the Tu'i Tonga had. Finnau 'Ulukālala-'i-Feletoa's short-lived son Moengangongo decreed after the death of Fuanunuiava in 1809 or 1810 that the Tu'i Tonga title would not be reappointed (Herda 1988:131); and Fuanunuiava was buried in an ordinary grave, a fa 'itoka rather than a royal tomb or langi ("sky") (ibid.:131-132). Moreover, he abolished the payment of first fruits or 'inasi to the Tu'i Tonga (ibid.). For historical reasons, the 'Ulukālalas did not propose to make common cause with the Vuna line either. "Rather than open conflict, Tu'i Vava'u Vuna instigated secret attacks and raids on 'Ulukālala and his supporters, while publicly entertaining them as visiting dignitaries. His intention appears to have been to undermine 'Ulukālala's ambitions by constantly reminding him of Vava'u's resistance to his rule" (Herda 1988:117).

22 According to Queen Sālote, this is how Fatu became ensconced at Mu'a: Originally he was located in Fua'amota with his mother's people. But Tāufa'āhau sent him to Mu'a after he had defeated Laufilitonga. Fatu was appointed to guard Laufilitonga and to curb any counter-insurgency ("Discussions" $1: 197)$.

23 According to Fusitu'a, the naming of Tungī and heirs as being in line to succeed occurred in 1888 (Fusitu'a 1976:17-18) while according to Ellem (1987) this took place in 1885.

24 Vuna, Tāufa'āhau's only legitimate son by Lupepau'u, had died in January 1862 (Campbell, pers.comm.); T vita 'Unga, his illegitimate son, had died in 1878; Uelingatoni Ngu Tupou Mālohi, T vita 'Unga's legitimate son, had died a bachelor in 1885; Laifone had died married but childless in 1889; and Fusipala, his daughter, had died in 1889 (Fusitu'a 1976:30).

25 Also a possible contender was a grandson of Tupou I by a secondary wife, Mateialona. He was Tupou II's classificatory father (Ellem 1981:96). Together with the Tu'i Pelehake and Sāteki Tonga (later Veikune), also associated with the Kauhala'uta, he encouraged Tupou II to marry Lavinia.

26 Herda questions the accuracy of the story about Tuapasi's bequest of the Tu'i Vava'u title on his deathbed. "In 1833, Tāufa'āhau assumed the rule of Vava'u claiming that on his deathbed. Tuapasi had passed his authority to his uho taha ... until his own son was of a ruling age. Interestingly, Tuapasi's last testament was not recorded by any of the European missionaries present at his death, but did appear in the papers of Thomas who was a staunch supporter of Tāufa'āhau. Significantly, Tuapasi's son was never named as Tu'i Vava'u nor as Fīnau 'Ulukālala”' (1988:134).

27 According to Queen Sālote, the original marriage plans for Uelingatoni Ngu Tupou Mālohi, first-born son of Tupou I's son by Fusima Taliti and who was Tupou I's lawful successor after T vita 'Unga died in 1879 - was to have married the daughter of Lavinia Veiongo and 'Inoke, so that the original intention was to merge Tu'i Kanokupolu and Tu'i Tonga blood, but these plans aborted because Ngu died in 1885; and even though his younger brother married Lavinia Veiongo's daughter, there were no offspring ("Discussions" 1:164). 